Article

\title{
Compounds with Antiviral, Anti-Inflammatory and Anticancer Activity Identified in Wine from Hungary's Tokaj Region via High Resolution Mass Spectrometry and Bioinformatics Analyses
}

\author{
Gergő Kalló ${ }^{1,2,+}$, Balázs Kunkli ${ }^{3,4,+} \mathbb{D}$, Zoltán Győri ${ }^{5}$ (D) Zoltán Szilvássy ${ }^{6}$, Éva Csósz ${ }^{1,2,+(\mathbb{D})}$ \\ and József Tózsér 1,2,3,*,‡(D) \\ 1 Proteomics Core Facility, Department of Biochemistry and Molecular Biology, Faculty of Medicine, \\ University of Debrecen, Egyetem tér 1, 4032 Debrecen, Hungary; kallo.gergo@med.unideb.hu (G.K.); \\ cseva@med.unideb.hu (É.C.) \\ 2 Biomarker Research Group, Department of Biochemistry and Molecular Biology, Faculty of Medicine, \\ University of Debrecen, Egyetem tér 1, 4032 Debrecen, Hungary \\ 3 Laboratory of Retroviral Biochemistry, Department of Biochemistry and Molecular Biology, \\ Faculty of Medicine, University of Debrecen, Egyetem tér 1, 4032 Debrecen, Hungary; \\ kunkli.balazs@med.unideb.hu \\ 4 Doctoral School of Molecular Cell and Immune Biology, University of Debrecen, Egyetem tér 1, \\ 4032 Debrecen, Hungary \\ 5 Institute of Food Science, Faculty of Agricultural and Food Sciences and Environmental Management, \\ University of Debrecen, Böszörményi út 128, 4032 Debrecen, Hungary; gyori.zoltan@unideb.hu \\ 6 Department of Pharmacology and Pharmacotherapy, Faculty of Medicine, University of Debrecen, \\ Egyetem tér 1, 4032 Debrecen, Hungary; szilvassy.zoltan@med.unideb.hu \\ * Correspondence: tozser@med.unideb.hu; Tel.: +36-52-416432; Fax: +36-52-314989 \\ + Equally contributing first authors. \\ $\ddagger$ Equally contributing last authors.
}

Received: 24 November 2020; Accepted: 14 December 2020; Published: 15 December 2020

\begin{abstract}
Background: Wine contains a variety of molecules with potential beneficial effects on human health. Our aim was to examine the wine components with high-resolution mass spectrometry including high-resolution tandem mass spectrometry in two wine types made from grapes with or without the fungus Botrytis cinerea, or "noble rot". (2) For LC-MS/MS analysis, 12 wine samples (7 without and 5 with noble rotting) from 4 different wineries were used and wine components were identified and quantified. (3) Results: 288 molecules were identified in the wines and the amount of 169 molecules was statistically significantly different between the two wine types. A database search was carried out to find the molecules, which were examined in functional studies so far, with high emphasis on molecules with antiviral, anti-inflammatory and anticancer activities. (4) Conclusions: A comprehensive functional dataset related to identified wine components is also provided highlighting the importance of components with potential health benefits.
\end{abstract}

Keywords: metabolomics; wine; LC-MS; functional food; high resolution mass spectrometry

\section{Introduction}

In recent years, products of grapes have received great interest due to the discovery that several of their components have beneficial health effects on the human metabolism [1-3]. While grapes are carbohydrate-rich fruits, their glycemic index is quite low [4]. Furthermore, the polyphenol levels in grapes are relatively high and studies suggest the benefits of the polyphenol content of grapes and 
grape products in the prevention or treatment of cardiovascular diseases and diabetes [5]. Despite the great variety of fermented drinks made from fruits, grape wine is the most widespread fruit alcohol. Wine production from grape, i.e., vinification, is a multi-step process where each step plays an important role in the quality of the produced wine. The vinification process of red and white wines is different in the processing of the grape berries while the fermentation processes are similar [6,7]. In Hungary, wines produced in the Tokaj Hegyalja region, a declared UNESCO World Heritage site, are classified as Hungaricum [8]. "Furmint" is a traditional Hungarian grapevine variety, and one of the components of the world famous "aszú" wine [9]. "Tokaji aszú" is produced by a special process called noble rotting of the grapes. The procedure of noble rotting is an interaction between the enzymatic activity of Botrytis cinerea and the concentrating effect of the dehydration [8]. Botrytis produces various oxidase and hydrolase enzymes leading to the conversion of numerous grape components such as polyphenols, flavonoids and nitrogenous substances [10]. The noble rotten grape berries have high sugar content and unique chemical composition of acids, polyphenols and aroma compounds [10]. The berries are combined with high quality "furmint" wine and after another fermentation process, "aszú" wine will be produced that contains many of the compounds of the noble rotten grape berries produced and modified by the enzymes of Botrytis cinerea [10]. Moreover, "Tokaji aszú" is the first wine type utilizing noble rotting [11]. Besides "Tokaji aszú", other type of wines are also utilizing the noble rotting process such as French Sauternes and German Trockenbeerenauslese wines [10].

The fact that wine was used as medicine in the ancient Mesopotamian and Chinese culture suggests the potential health benefits of wine components [12]. During the last decade, different studies have shown the health beneficial effects of wine polyphenols [13-17] suggesting that wine could be used as a functional food [12]. However, wine contains many other biologically important components that highlight the importance of the deep analysis of wine compounds.

The analysis of wine compounds includes different analytical techniques such as nuclear magnetic resonance (NMR) [18], infrared spectroscopy [8], gas chromatography-mass spectrometry (GC-MS) and liquid chromatography-mass spectrometry (LC-MS) [7]. The NMR technique is widely used for the analysis of the quality and the originality of different wines $[18,19]$. Although the NMR is very important for the quality control process of the winemaking procedure, the emerging mass spectrometry techniques can provide sensitive identification and quantification of hundreds of molecules in the wines. In spite of the recent improvements, the sensitivity is still a weak point of the NMR compared to mass spectrometry; the mass spectrometry-based metabolomics methods provide a more sensitive approach. Mass spectrometry enables the application of various ionization techniques and mass analyzers in order to increase the number of detected metabolites. With the application of mass spectrometry techniques, the differences between the wine types and wineries can be analyzed. In this study, our aim was to examine the wine components, to identify the components with health beneficial effects and to compare the small molecule content of different "furmint" and "aszú" wines originated from four wineries.

\section{Results}

In this study, we have analyzed 12 wine samples with data-dependent mass spectrometry acquisition using both positive and negative polarity modes in order to examine the different wine components. After data evaluation, 288 components were identified based on the acquired MS/MS spectra (Table S1). Based on the literature mining, 253 components were not reported in wines previously and these novel wine components were highlighted in Table S1. The identified compounds were subjected to comparative analysis using the normalized peak areas.

\subsection{Biological Roles of the Identified Wine Compounds}

The 288 identified compounds were subjected to analysis in the PubChem BioAssay database, and 137 molecules out of the 288 were found to have biological activity (Table S2). The collected PubChem identifiers were searched in the PUG-View database, as well. The acquired dataset was 
searched for compound description and information about biochemistry and human biochemistry, pharmacology, drug-medication and FDA safety hazard. In the PUG-View, 140 molecules out of the 288 hits were found (Table S3). In order to gain more data about the health beneficial effects of the identified molecules, the results of the search in the BioAssay database were further filtered to collect molecules with antiviral, anti-inflammatory and anticancer activity. Some highlights are given in Table 1, and detailed information is listed in Table S4.

Table 1. Antiviral, anticancer and anti-inflammatory roles of representative compounds found in wine. The full list of the compounds with detailed biological role and references are listed in Table S4.

\begin{tabular}{|c|c|c|}
\hline Compound Name & PubChem ID & Role, Biological Activity \\
\hline Achalensolide & 21634938 & NF- $k B$ inhibitory activity in Jurkat $\mathrm{T}$ cells \\
\hline DL-alanyl-DL-phenylalanine & 2080 & $\begin{array}{l}\text { Cytotoxic effect against aggressive human metastatic } \\
\text { breast adenocarcinoma MDA-MB-231 and MCF-7 cells }\end{array}$ \\
\hline \multirow{2}{*}{ Asperlin } & \multirow{2}{*}{35319} & $\begin{array}{c}\text { Induction of apoptosis via ROS production in human } \\
\text { cervical carcinoma HeLa cells }\end{array}$ \\
\hline & & $\begin{array}{l}\text { Inhibition of iNOS, suppression of COX-2 expression, } \\
\text { reduction in COX-derived PGE2 }\end{array}$ \\
\hline Bestatin & 439299 & Antiviral activity against coronaviruses \\
\hline \multirow[t]{2}{*}{ Caffeic acid } & \multirow[t]{2}{*}{689043} & $\begin{array}{c}\text { Anticancer activity against human cell lines originating } \\
\text { from breast cancer (MCF-7, MDA-MB-231) cervical cancer } \\
\text { (HeLa), metastatic cervical cancer (SiHa), hepatocellular } \\
\text { carcinoma (HepG2, Huh7), lung cancer (A-549), } \\
\text { colon carcinoma (HT29-D4, HCT 15), melanoma } \\
\text { (SK-Mel-28), oral squamous cell carcinoma (SCC-25), } \\
\text { gastric cancer (SCM1), suppression of UVB-induced } \\
\text { skin carcinogenesis }\end{array}$ \\
\hline & & $\begin{array}{l}\text { Reduction in lipid peroxidation and of TNF- } \alpha, \text { IL- } 6 \text {, IL-1 } \beta \text {, } \\
\text { IFN- } \gamma, \text { NF- } \mathrm{kB} / \text { p } 65 \text { and TGF- } \beta \text { levels }\end{array}$ \\
\hline \multirow[b]{2}{*}{ Dimethylcaffeic acid } & \multirow[b]{2}{*}{717531} & Antiviral activity against HIV-1 \\
\hline & & $\begin{array}{l}\text { Beneficial effect in prostate-, thymus- and stomach-, } \\
\text { lung- and brain cancer }\end{array}$ \\
\hline \multirow{3}{*}{ (E)-Ethyl caffeate } & \multirow{3}{*}{5317238} & Antiviral activity against HBV, HIV-1 \\
\hline & & $\begin{array}{c}\text { Anticancer activity against cancer cell lines: human } \\
\text { hepatocellular carcinoma BEL-7404 and HepG2, SK-OV-3 } \\
\text { human ovarian cancer, human breast MCF-7 } \\
\text { adenocarcinoma, human lung A549 adenocarcinoma and } \\
\text { human gastric cancer BCG823 }\end{array}$ \\
\hline & & $\begin{array}{l}\text { Suppression of NF- } \mathrm{kB} \text { activation and its downstream } \\
\text { inflammatory mediators, iNOS, COX-2, and PGE2 }\end{array}$ \\
\hline \multirow{3}{*}{ Chlorogenic acid } & \multirow{3}{*}{1794427} & $\begin{array}{l}\text { Antiviral activity against hepatitis C, hepatitis B, Ebola } \\
\text { virus, HIV-1, adenoviruses, H1N1/H3N2 influenza strains }\end{array}$ \\
\hline & & $\begin{array}{l}\text { Anticancer activity against human cell lines originating } \\
\text { from breast cancer (MCF-7, MDA-MB-231), cervical } \\
\text { cancer (HeLa), hepatocellular carcinoma (HepG2), } \\
\text { lung cancer (A-549), colon carcinoma (CT-26, Caco-2, } \\
\text { HT29-D4, HCT 116), melanoma (SK-Mel-28), } \\
\text { oral squamous cell carcinoma (HSC-2), salivary gland } \\
\text { cancer (HSG), pancreatic cancer (PANC-1), leukemia } \\
\text { (U937, HL-60, K562), prostate cancer (DU145) }\end{array}$ \\
\hline & & $\begin{array}{l}\text { Anti-inflammatory activity, inhibition of } \mathrm{NO} \text { and } \\
\text { proinflammatory cytokine production }\end{array}$ \\
\hline
\end{tabular}


Table 1. Cont.

\begin{tabular}{|c|c|c|}
\hline Compound Name & PubChem ID & Role, Biological Activity \\
\hline \multirow[b]{2}{*}{ Coumarin } & \multirow[b]{2}{*}{323} & $\begin{array}{l}\text { Coumarin derivatives exert anti-coagulant, anti-tumor, } \\
\text { anti-viral, anti-inflammatory and antioxidant effects, } \\
\text { as well as anti-microbial and enzyme inhibition properties }\end{array}$ \\
\hline & & $\begin{array}{l}\text { Anticancer activity against human cell lines originating } \\
\text { from gastric carcinoma, colon-carcinoma cell line (Caco-2), } \\
\text { hepatoma-derived cell line (HepG2), lymphoblastic cell } \\
\text { line (CCRF CEM), lung adenocarcinoma (A427, Calu-1, } \\
\text { SK-MES-1, SK-LU-1), renal carcinoma (786-O, A-498), } \\
\text { malignant prostatic cancer (DU145, LNCaP), beneficial } \\
\text { effects in renal cell carcinoma and malignant melanoma }\end{array}$ \\
\hline \multirow{3}{*}{ (E)-p-coumaric acid } & \multirow{3}{*}{637542} & $\begin{array}{c}\text { Antiviral activity against oseltamivir- and } \\
\text { peramivir-sensitive and oseltamivir- and } \\
\text { peramivir-resistant influenza viruses and hepatitis C }\end{array}$ \\
\hline & & $\begin{array}{l}\text { Anticancer activity in mammalian, colon and hepatic } \\
\text { cancer and neuroblastoma cell lines }\end{array}$ \\
\hline & & $\begin{array}{l}\text { Inhibition of the STAT1 activation, decrease in TNF- } \alpha \\
\text { expression, ROS scavenger function }\end{array}$ \\
\hline Cyclo(phenylalanyl-prolyl) & 99895 & $\begin{array}{l}\text { Growth inhibition and apoptosis induction in HT-29 } \\
\text { colon cancer cells }\end{array}$ \\
\hline \multirow{3}{*}{ Dehydrocostus lactone } & \multirow{3}{*}{73174} & Inhibition of Norovirus infection \\
\hline & & $\begin{array}{l}\text { Anticancer activity against human cell lines originating } \\
\text { from ovarian cancer (SK-OV-3), breast cancer (MCF-7, } \\
\text { MDA-MB-231), cervical cancer (HeLa), hepatocellular } \\
\text { carcinoma (HepG2), lung adenocarcinoma (A-549, } \\
\text { NCI-H520, NCI-H460), prostate cancer (DU145), sarcoma } \\
\text { (liposarcoma-SW-872, synovial sarcoma - SW-982, TE-671 } \\
\text { - rhabdomyosarcoma), neuroblastoma (IMR-32, NB-39, } \\
\text { SK-N-SH, LA-N-1) }\end{array}$ \\
\hline & & $\begin{array}{c}\text { Reduced production of chemokines induced by TNF- } \alpha \\
\text { and IFN- } \gamma\end{array}$ \\
\hline Dodecanedioic acid & 12736 & Cytotoxic effect on B16 melanoma cells \\
\hline \multirow[t]{2}{*}{ Eicosapentaenoic acid } & \multirow[t]{2}{*}{446284} & $\begin{array}{l}\text { Growth inhibition effect on colon cancer cell lines (HT-29, } \\
\text { Caco-2, DLD-1), antiproliferative effects on hepatoma } \\
\text { (HepG2), leukemia (HL-60) cell lines, inhibition of } \\
\text { macrophage-induced gastric cancer cell migration }\end{array}$ \\
\hline & & $\begin{array}{l}\text { Attenuation of pro-inflammatory properties of VLDL via } \\
\text { decrease in lipoprotein-lipase activity to hydrolyze VLDL }\end{array}$ \\
\hline \multirow{3}{*}{ Ethyl gallate } & \multirow{3}{*}{13250} & Anti-herpes simplex virus type 1 activity \\
\hline & & $\begin{array}{l}\text { Anticancer activity against human cell lines originating } \\
\text { from leukemia (HL-60), prostate cancer (PC-3), } \\
\text { human (MCF-7) and mouse (S115) breast cancer, } \\
\text { osteosarcoma (HOS-1), ovarian cancer (OVCAR-3), } \\
\text { renal cancer (A-498), lung cancer (NCI-H460), } \\
\text { colon cancer (KM20L2) and melanoma (SK-MEL-5) }\end{array}$ \\
\hline & & $\begin{array}{l}\text { Inhibition of LPS induced cell adhesion molecules } \\
\text { expression, attenuation of acute lung injury }\end{array}$ \\
\hline Fertaric acid & 22298372 & Hepatoprotective effects \\
\hline
\end{tabular}


Table 1. Cont.

\begin{tabular}{|c|c|c|}
\hline Compound Name & PubChem ID & Role, Biological Activity \\
\hline 16-Heptadecyne-1,2,4-triol & 3015189 & $\begin{array}{l}\text { Cytotoxic activity in human lung carcinoma (A-549), } \\
\text { mammary adenocarcinoma (MCF-7), } \\
\text { colon adenocarcinoma (HT-29), kidney carcinoma (A-498), } \\
\text { pancreatic carcinoma (PaCa-2), prostate adenocarcinoma } \\
\text { (PC-3) cell lines }\end{array}$ \\
\hline L-Histidinol & 165271 & $\begin{array}{l}\text { Pro-apoptotic activity in CCRF-CEM human leukemia cell } \\
\text { line, inhibition of B16 melanoma cell proliferation }\end{array}$ \\
\hline \multirow{3}{*}{ Indole-3-carbinol } & \multirow{3}{*}{3712} & $\begin{array}{c}\text { Promotion of apoptosis of Epstein-Barr virus } \\
\text { (EBV)-positive but not of EBV-negative Burkitt's } \\
\text { lymphoma cell lines }\end{array}$ \\
\hline & & $\begin{array}{l}\text { Anticancer activity against human cell lines originating } \\
\text { from various cancer types such as prostate cancer (LnCaP, } \\
\text { PC-3), breast cancer (MCF7, MDA-MB-468, MDA-MB-231, } \\
\text { HBL100), colon cancer (HT-29, HCT-116), lung cancer } \\
\text { (A-549), cervical cancer (CaSki, SiHa, C33-A), melanoma } \\
\text { (SK-MEL-2, SK-MEL-5), ovarian cancer (SK-OV-3), } \\
\text { oral squamous cell carcinoma (SCC2095, SCC9, SCC15), } \\
\text { hepatocellular carcinoma (HepG2, Huh-7, SNU449), } \\
\text { pancreatic cancer (BxPC-3, Mia Paca-2, PL-45, AsPC-1, } \\
\text { PANC-1), leukemia (U937, HL-60, K562, BCP-ALL } \\
\text { NALM-6), osteosarcoma (U2OS) etc. }\end{array}$ \\
\hline & & $\begin{array}{l}\text { Reversal of liver fibrosis, reduction in hepatocyte } \\
\text { degeneration, necrosis, promotion of hepatic stellate cell } \\
\text { apoptosis, anti-inflammatory effects by inhibiting the } \\
\text { productions of NO, TNF-alpha, and IL-10 }\end{array}$ \\
\hline Kynurenic acid & 3845 & $\begin{array}{l}\text { Modulation of IL-23 and IL-17 expression in dendritic } \\
\text { cells and Th17 cells }\end{array}$ \\
\hline Linamarin & 11128 & Cytotoxic effects on MCF-7, HT-29 and HL60 cell lines \\
\hline \multirow{3}{*}{ Melatonin } & \multirow{3}{*}{896} & $\begin{array}{c}\text { Indirect support against Ebola virus infection, } \\
\text { Potential adjuvant treatment in COVID-19, and other } \\
\text { viral infections }\end{array}$ \\
\hline & & $\begin{array}{l}\text { Upregulation of Fas/Fas ligand in Ewing's sarcoma cells, } \\
\text { cell cycle arrest and apoptosis in hepatocarcinoma HepG2 } \\
\text { cell line, induction of pro-apoptotic signaling pathway in } \\
\text { human pancreatic carcinoma cells, anticancer activity in } \\
\text { breast cancer (MCF-7) cells, inhibition of the proliferation } \\
\text { and invasion of glioma cells, lung adenocarcinoma } \\
\text { (A-549) cells, inhibition of estrogen receptor } \\
\text { transactivation in breast cancer cells, negative mitogenic } \\
\text { hormonal regulator of human prostate epithelial cells }\end{array}$ \\
\hline & & $\begin{array}{l}\text { Decreases serum and tissue inflammatory cytokines } \\
\text { levels, tissue lipid peroxidation and neutrophil infiltration }\end{array}$ \\
\hline \multirow{2}{*}{$\begin{array}{l}\text { 9S,13R-12-Oxophytodienoic } \\
\text { acid }\end{array}$} & \multirow{2}{*}{14037063} & $\begin{array}{l}\text { Induces growth arrest in MDA-MB-231 and T47D breast } \\
\text { cancer cells followed by progressive reduction in cyclin } \\
\text { D1 expression }\end{array}$ \\
\hline & & $\begin{array}{l}\text { Suppression of NF- } \kappa \text { B, inhibition of p38, and activation of } \\
\text { SOCS-1 signaling }\end{array}$ \\
\hline Perlolyrine & 160179 & $\begin{array}{l}\text { Antiproliferative activity against human stomach cancer } \\
\text { cell lines }\end{array}$ \\
\hline Phytosphingosine & 122121 & $\begin{array}{l}\text { Induction of apoptotic cell death via caspase } 8 \text { activation } \\
\text { and Bax translocation in human cancer cells }\end{array}$ \\
\hline
\end{tabular}


Table 1. Cont.

\begin{tabular}{|c|c|c|}
\hline Compound Name & PubChem ID & Role, Biological Activity \\
\hline \multirow{3}{*}{ Quercetin } & \multirow{3}{*}{5280343} & $\begin{array}{l}\text { Antiviral activity against HIV-1, hepatitis B and C viruses, } \\
\text { adenoviruses, herpes simplex viruses, noroviruses, H1N1, } \\
\text { H5N1 etc. }\end{array}$ \\
\hline & & $\begin{array}{l}\text { Anticancer activity against human cell lines originating } \\
\text { from various cancer types such as breast cancer (MCF7), } \\
\text { colon cancer (HT-29, HCT-116, Caco-2, DLD-1), } \\
\text { lung cancer (A-549), esophageal squamous cell carcinoma } \\
\text { cell line (KYSE-510, OE33), cervical cancer (HeLa), } \\
\text { oral squamous cell carcinoma (SCC9), hepatocellular } \\
\text { carcinoma (HepG2), leukemia (U937, HL-60), } \\
\text { osteosarcoma (MG-63), pancreatic cancer (PC3, } \\
\text { EPP85-181P, EPP85-181RDB), melanoma (B16F10), } \\
\text { glioma (U87, U139MG), inhibition of angiogenesis in } \\
\text { tamoxifen-resistant breast cancer cells }\end{array}$ \\
\hline & & $\begin{array}{c}\text { Inhibition of inflammatory cytokine production, } \\
\text { Inhibition of histamine release, Reduction in neutrophil } \\
\text { recruitment, Ameliorating endothelial insulin resistance } \\
\text { through inhibition of reactive oxygen species-associated } \\
\text { inflammation. }\end{array}$ \\
\hline (-)-Rhododendrin & 442538 & Inhibition of toll-like receptor-7-mediated inflammation \\
\hline Sphinganine & 91486 & $\begin{array}{l}\text { Anticancer activity against human cell lines originating } \\
\text { from leukemia (HL-60), prostate cancer (PC-3, LnCaP), } \\
\text { breast cancer (MDA-MB-231), colon cancer (HT-29, } \\
\text { HCT-116) and melanoma (939, 294, C8161, A2058), } \\
\text { oral squamous cell carcinoma (SAS, Ca9-22, HSC-3) }\end{array}$ \\
\hline \multirow{3}{*}{ Taxifolin } & \multirow{3}{*}{439533} & $\begin{array}{c}\text { Antiviral activity against HIV-1, coxsackieviruses B4, } \\
\text { hepatitis A }\end{array}$ \\
\hline & & $\begin{array}{l}\text { Anticancer effect due to Nrf2, inflammatory and } \\
\text { Wnt/ } \beta \text {-catenin cascade modulation, inhibition of breast } \\
\text { cancer MDA-MB-231 and } 4 \mathrm{~T} 1 \text { cell proliferation, cell cycle } \\
\text { arrest in human colorectal cancer HCT116 and HT29 cells, } \\
\text { activation of apoptosis in prostate carcinoma DU145 cells }\end{array}$ \\
\hline & & $\begin{array}{c}\text { Antioxidant and anti-inflammatory effects by inhibition of } \\
\text { NO and PGE2 production, ICAM-1, COX-2 and PLA2 } \\
\text { expression }\end{array}$ \\
\hline $\begin{array}{l}\text { Tetrahydroharman-3-carboxylic } \\
\text { acid }\end{array}$ & 73530 & Inhibition of nitric oxide and prostaglandin E2 production \\
\hline \multirow{3}{*}{ Umbelliferone } & \multirow{3}{*}{5281426} & Antiviral activity against HIV-1 \\
\hline & & $\begin{array}{l}\text { Cytostatic activity in human malignant cell lines A549, } \\
\text { ACHN, Caki-2, Dakiki, HS-Sultan, H727, HCT-15, HL-60, } \\
\text { K562, LNCaP, PC-3, Du 145 COLO-232, MCF-7 and } \\
\text { RP-1788; stimulation of apoptosis in HL-60 cells, } \\
\text { Growth inhibition of human bladder carcinoma E-J cell } \\
\text { line, lung adenocarcinoma A-427 cells, proliferation } \\
\text { inhibition of gastric carcinoma, colon-carcinoma (Caco-2), } \\
\text { a hepatoma-derived (HepG2), and a lymphoblastic cell } \\
\text { line (CCRF CEM), chemoprotective effect in early-stage } \\
\text { (Ln- Cap) and late-stage (PC3) prostate cancer cells }\end{array}$ \\
\hline & & $\begin{array}{l}\text { Anti-inflammatory and antipyretic effects, reduction of } \\
\text { IL-4, IL-5 and IL-13, suppression of Th1 cytokine } \\
\text { production during influenza virus infection }\end{array}$ \\
\hline Zedoarondiol & 14632997 & $\begin{array}{l}\text { Inhibition of iNOS, COX-2 activity and of the production } \\
\text { of NO, PGE2, TNF-alpha, IL-6, and IL-1beta }\end{array}$ \\
\hline
\end{tabular}




\subsection{Comparative Analysis of "aszú" and "furmint" Wines}

Data acquired in positive and negative polarity modes were subjected to principal component analysis (Figure 1). Regarding the results, the differentiation between the "aszú" and "furmint" samples was successful using the data acquired both in positive (Figure 1A) and negative (Figure 1B) polarity modes. Besides the differentiation of the "aszú" and "furmint" wine types, we could also differentiate between the wineries using the data from positive polarity mode experiments $(57.3 \%)$. In case of the data acquired in negative polarity mode, the differentiation of the wineries was not accurate enough $(53 \%)$.
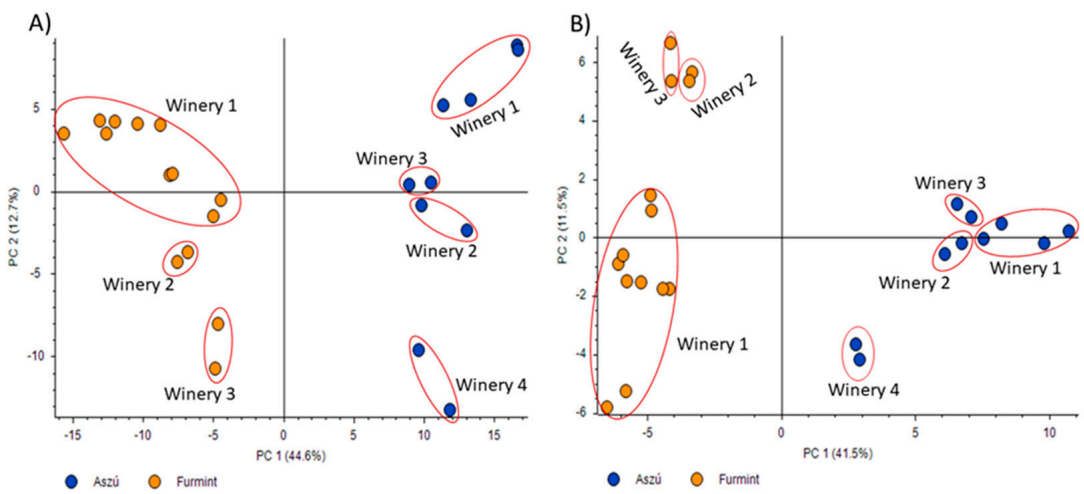

Figure 1. Principal component analysis of "aszú" and "furmint" wine samples analyzed in positive panel (A) and negative panel (B) polarity mode. The " $x$ " axis shows PC1 while the " $y$ " axis shows PC2. The orange dots represent the "furmint" samples while the blue dots represent the "aszú" samples.

The wineries are also indicated with numbering.

The acquired data were also subjected to hierarchical cluster analysis and heat maps were generated (Figure 2). The differentiation between the "aszú" and "furmint" wines was successful using the data registered in both positive (Figure 2A) and negative (Figure 2B) polarity mode. The "furmint" samples were clustered by the wineries in case of positive mode, while in negative polarity mode, the clustering was not as accurate as in positive mode. In case of the "aszú" samples, we observed that the clustering by wineries was successful in negative polarity mode, but not in positive mode. Based on the heat maps, several clusters of differentially expressed molecules between the two studied wine types could be identified.
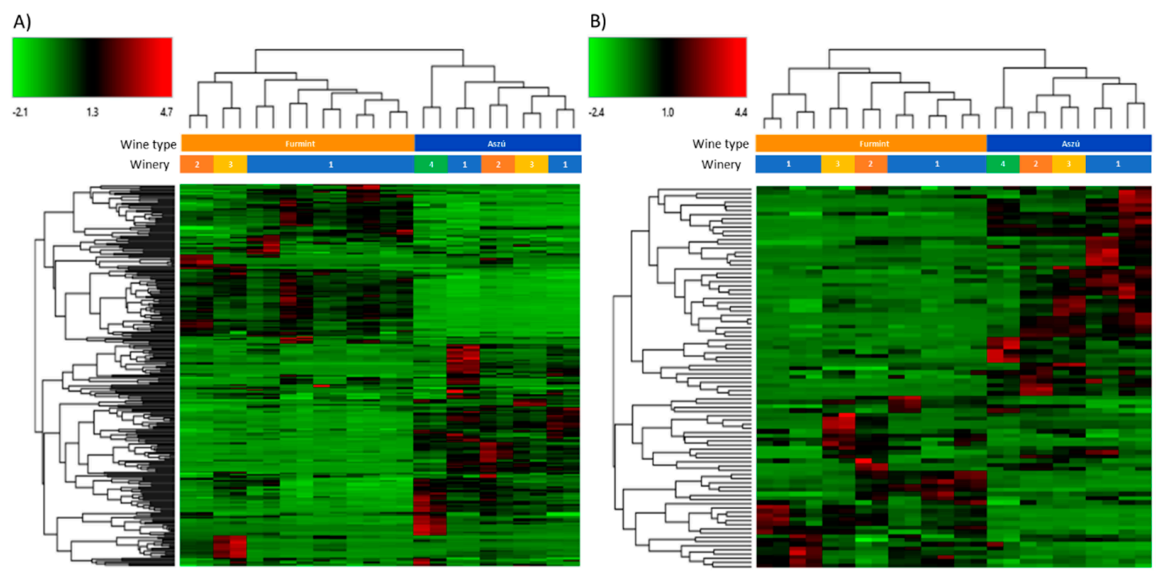

Figure 2. Hierarchical cluster analysis of the molecules identified in "aszú" and "furmint" wines registered in positive panel (A) and in negative panel (B) polarity mode. The green color indicates compounds with lower amount, while the red color shows compounds with higher amount in the comparison of "aszú" and "furmint" samples. 
After fold change analysis, 169 molecules with $\pm 1 \log 2$ fold change and with $p<0.05$ between the "aszú" and "furmint" groups were identified (Figure 3, Table S5).

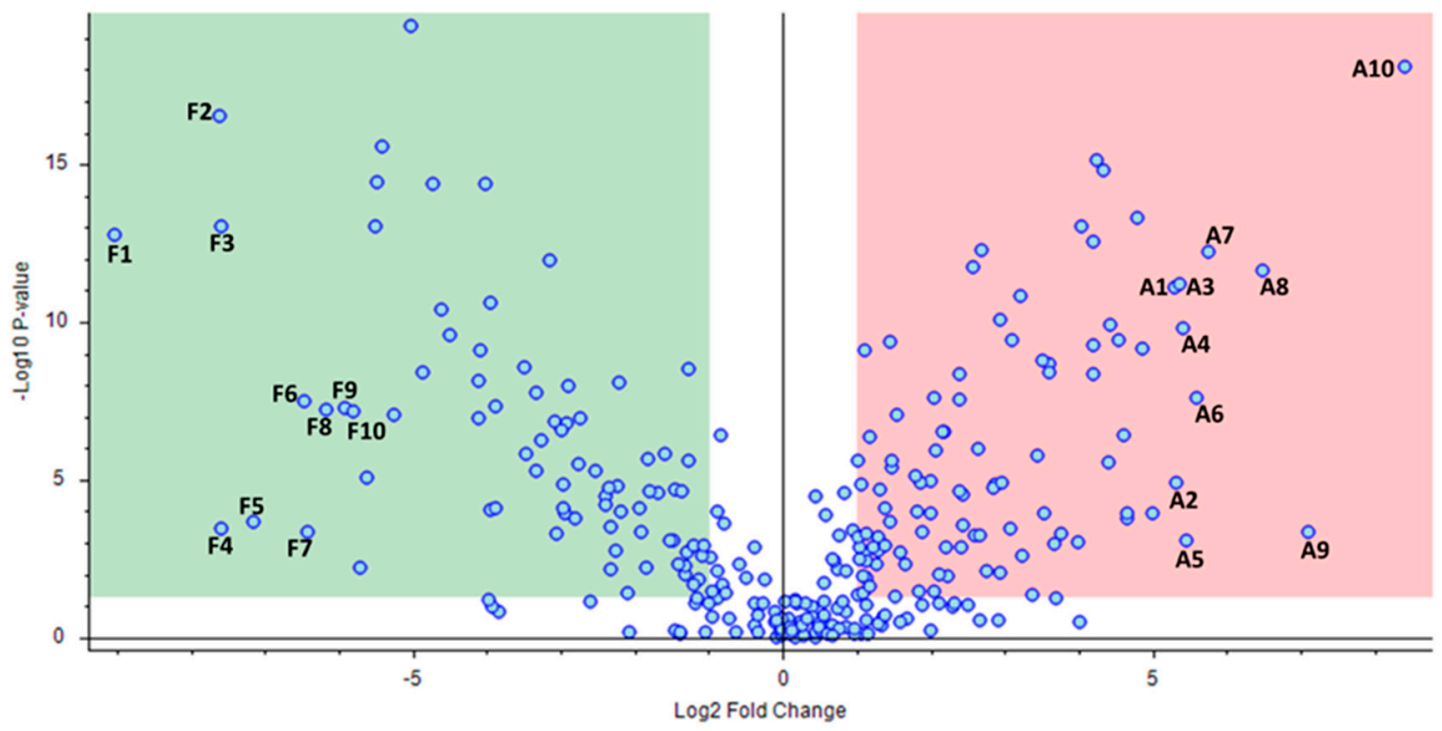

Figure 3. Comparative analysis of the identified compounds in "aszú" and "furmint" wines. The " $x$ " axis represents the Log2 fold-change values, while the " $y$ " axis indicates the $-\log 10 p$ values. The green box sows the compounds having statistically significantly higher level in "furmint" compared to "aszú", while the red box indicates compounds with statistically significantly higher level in "aszú" compared to "furmint". The top 10 components that showed the highest change in "furmint" and in "aszú", repsepectively, are denoted with numbers (F1-F10 and A1-A10, respectively). F1: DL-isoleucyl-DL-isoleucyl-DL-histidine, F2: DL-alanyl-DL-isoleucyl-DL-isoleucyl-DL-threonine, F3: DL-leucyl-DL-leucyl-DL-leucine, F4: DL-valyl-DL-valyl-DL-valine, F5: L-phenylalanyl-L-leucine, F6: DL-tyrosyl-DL-prolyl-DL-isoleucine, F7: (2S)-2-[(2R)-7-(2-Methoxyethoxy)-5,8-dimethyl-1,2,3,4tetrahydro-2-naphthalenyl]-1-(1-piperidinyl)-1-propanone, F8: DL-isoleucyl-DL-alpha-glutamylDL-lysine, F9: 1-(4-Methoxyphenyl)-N-[3-(4-morpholinyl)propyl]-5-oxo-3-pyrrolidinecarboxamide, F10: N- Isobutyrylglycylglycine, A1: Phenethylamine, A2: Perillartine, A3: DL-glutaminyl-DL-threonylDL-lysine, A4: N-Boc-Tyramine, A5: 4-(2,3-Dihydro-1,4-benzodioxin-6-yl)-4-oxobutanoic acid, A6: 1- Hydroxyhexane-1,2,6-tricarboxylate, A7: 2-Hydroxy-1-(6-hydroxy-2-isopropenyl-2,3-dihydro-1benzofuran-5-yl)ethanone, A8: Rosin, A9: (2E)-3-(3,4-dimethoxyphenyl)prop-2-enoic acid, A10: N-[3-(4, 11-Dimethyl-2-oxo-6,7,8,9-tetrahydro-2H-[1]benzofuro[3,2-g]chromen-3-yl)propanoyl]glycine.

The top 10 molecules with the highest changes in "furmint" and top 10 molecules with the highest changes in "aszú" were further analyzed, and the biological roles of these molecules [20-31] are shown in Table 2.

Table 2. Biological roles of the top 10 differentially expressed molecules in "aszú" and the top 10 differentially expressed molecules in "furmint" wines. The name, $\log 2$ fold change, adjusted $p$-value and the biological role is indicated in case of each compound. Negative fold change represents significantly higher level in "furmint", while positive fold change shows significantly higher level in "aszú".

\begin{tabular}{cccc}
\hline Name & Log2 Fold Change & Adjusted $p$-Value & Biological Roles \\
\hline DL-isoleucyl-DL-isoleucyl-DL-histidine & -9.04 & $2.43 \times 10^{-11}$ & No information \\
\hline $\begin{array}{c}\text { DL-alanyl-DL-isoleucyl-DL-isoleucyl- } \\
\text { DL-threonine }\end{array}$ & -7.62 & $2.18 \times 10^{-14}$ & No information \\
\hline DL-leucyl-DL-leucyl-DL-leucine & -7.60 & $1.43 \times 10^{-11}$ & No information \\
\hline DL-valyl-DL-valyl-DL-valine & -7.58 & $1.35 \times 10^{-3}$ & No information \\
\hline
\end{tabular}


Table 2. Cont.

\begin{tabular}{|c|c|c|c|}
\hline Name & Log2 Fold Change & Adjusted $p$-Value & Biological Roles \\
\hline \multirow[t]{2}{*}{ L-phenylalanyl-L-leucine } & \multirow[t]{2}{*}{-7.16} & \multirow[t]{2}{*}{$8.81 \times 10^{-4}$} & $\begin{array}{c}\text { Membrane } \\
\text { metalloendopeptidase } \\
\text { inhibitor in mouse model [20] }\end{array}$ \\
\hline & & & Plant metabolite \\
\hline DL-tyrosyl-DL-prolyl-DL-isoleucine & -6.46 & $5.77 \times 10^{-7}$ & No information \\
\hline $\begin{array}{c}\text { (2S)-2-[(2R)-7-(2-Methoxyethoxy)-5,8- } \\
\text { dimethyl-1,2,3,4-tetrahydro-2-naphthalenyl]- } \\
\text { 1-(1-piperidinyl)-1-propanone }\end{array}$ & -6.42 & $1.76 \times 10^{-3}$ & No information \\
\hline DL-isoleucyl-DL-alpha-glutamyl-DL-lysine & -6.18 & $9.00 \times 10^{-7}$ & No information \\
\hline $\begin{array}{l}\text { 1-(4-Methoxyphenyl)-N-[3-(4-morpholinyl) } \\
\text { propyl]-5-oxo-3-pyrrolidine carboxamide }\end{array}$ & -5.92 & $7.99 \times 10^{-7}$ & $\begin{array}{c}\text { Phosphoethanolamine/ } \\
\text { phosphocholine phosphatase } 1 \\
\text { inhibitor [21] }\end{array}$ \\
\hline N-Isobutyrylglycylglycine & -5.79 & $1.04 \times 10^{-6}$ & No information \\
\hline Phenethylamine & 5.29 & $5.97 \times 10^{-10}$ & $\begin{array}{l}\text { 5-hydroxytryptamine receptor } \\
\text { agonist in rat [22,23] } \\
\text { CYP450 inhibitor [24] } \\
\text { Trace amine associated } \\
\text { receptor agonist [25] }\end{array}$ \\
\hline Perillartine & 5.32 & $7.90 \times 10^{-5}$ & No information \\
\hline DL-glutaminyl-DL-threonyl-DL-lysine & 5.37 & $4.92 \times 10^{-10}$ & No information \\
\hline N-Boc-Tyramine & 5.40 & $6.91 \times 10^{-9}$ & No information \\
\hline $\begin{array}{l}\text { 4-(2,3-Dihydro-1,4-benzodioxin-6-yl)- } \\
\text { 4-oxobutanoic acid }\end{array}$ & 5.45 & $2.92 \times 10^{-3}$ & $\begin{array}{l}\text { Neuropeptide } Y \text { receptor } \\
\text { agonist [26-28] } \\
\text { Thyroid stimulating hormone } \\
\text { receptor agonist [29] }\end{array}$ \\
\hline 1-Hydroxyhexane-1,2,6-tricarboxylate & 5.58 & $4.60 \times 10^{-7}$ & No information \\
\hline $\begin{array}{l}\text { 2-Hydroxy-1-(6-hydroxy-2-isopropenyl- } \\
\text { 2,3-dihydro-1-benzofuran-5-yl)ethanone }\end{array}$ & 5.75 & $7.35 \times 10^{-11}$ & No information \\
\hline Rosin & 6.49 & $2.23 \times 10^{-10}$ & No information \\
\hline $\begin{array}{l}\text { (2E)-3-(3,4-dimethoxypheny)prop- 2-enoic } \\
\text { acid }\end{array}$ & 7.11 & $1.77 \times 10^{-3}$ & $\begin{array}{c}\text { Inhibitors of } \\
\text { HSD17B4|hydroxysteroid } \\
\text { (17-beta) dehydrogenase } 4 \text { [30] } \\
\text { Antihemorrhagic activity in } \\
\text { ddY mouse [31] }\end{array}$ \\
\hline $\begin{array}{l}\mathrm{N} \text {-[3-(4,11-Dimethyl-2-oxo-6,7,8,9- } \\
\text { tetrahydro-2H-[1]benzofuro[3,2-g] } \\
\text { chromen-3-yl)propanoyl]glycine }\end{array}$ & 8.42 & $1.57 \times 10^{-15}$ & No information \\
\hline
\end{tabular}

\section{Discussion}

Appearing in ancient books, wine has been considered for a long time to be a preparation with health beneficial effects [12]. These effects are mainly attributed to the different phytochemicals present in wine, but there were also studies which demonstrated the beneficial effect of low doses of alcohol [32,33]. However, according to current studies, there are contradictory data regarding the beneficial or harmful effect of alcohol consumption [33]. Considering these data, we do not intend either to promote or discourage alcohol consumption; with this study, we aimed to carry out, with scientific rigorousness, a metabolomics examination of wine components followed by bioinformatics analysis.

The metabolomics analysis of "aszú" and "furmint" wine types identified altogether 288 different components. Although many common compounds were found in the two different wine types, we have identified 169 molecules characteristic either to "aszú" or "furmint". The production of "furmint" and "aszú" wines are different, therefore, even though "aszú" is based on further processing and modification of "furmint" their composition is expected to be different, as well. In this pilot study, we have successfully differentiated the "aszú" wines involving berries having undergone noble rotting from the "furmint" wines based on the identified molecules and their relative quantities. 
Phenolic compounds of the wine, including phenolic acids, flavonols, stilbenoids, dihydroflavonols, anthocyanins and flavanol monomers and polymers, influence the color and the taste of the wines. This large group of phenols can be separated into two broad groups, flavonoids and non-flavonoids [34,35]. Our analyses identified many phenolic compounds in the "aszú" and "furmint" wines such as 3-feruloylquinic acid, caffeic acid, caffeic acid 3-sulfate, chlorogenic acid, ethyl caffeate, dimethylcaffeic acid, ethyl gallate, fertaric acid, gentisic acid, rhododendrine and quercetin, and the compound annotation revealed that many identified phenolic compounds have antiviral, anticancer and anti-inflammatory activities. The statistical analysis has not shown statistically significant differences in the levels of caffeic acid, ethyl caffeate, ethyl gallate, fertaric acid, gentisic acid and quercetin between the "aszú" and "furmint" wines. The level of caffeic acid 3-sulfate and rhododendrine was significantly higher in "aszú" wines while the level of 3-feruloylquinic acid and chlorogenic acid was significantly higher in "furmint" wines. The reason behind the different level of several polyphenols in the different wines can be the additional fermentation process of the "aszú" wines and/or the infection of the grape berries with Botrytis cinerea [10].

Further studies are needed to gain more insights into the composition of wines, but our study has shown the power of LC-MS/MS-based metabolomics in wine examination. By applying the mass-spectrometry-based methods able to generate both qualitative and quantitative information, molecular fingerprints of different wines based on their compounds can possibly be created. By the bioinformatics analysis of the biological function of the wine components, we could generate comprehensive lists of the wine components highlighting their antiviral, anticancer and anti-inflammatory properties.

Viral outbreaks represent critical threat to the public health, particularly when vaccines or effective antiviral therapies are not available [36]. Viral infections can be responsible for significant global mortality and can be associated with several complex diseases such as Alzheimer's disease, diabetes or cancer [37]. Herbal and fruit extract are well known sources of antiviral agents [37-40] providing new tools for the development of antiviral therapies. Phenolic compounds such as chlorogenic acid, ethyl caffeate, dimethylcaffeic acid, ethyl gallate, quercetin and taxifolin exert a wide range of antiviral activities against different viruses such as HIV-1 [41-48], hepatitis A, B and C virus [49-54], influenza virus [55-61], adenovirus [62,63], herpes simplex virus [62-65], enterovirus 71 [66,67], SARS-CoV [68], rhinovirus [69], Epstein-Barr virus [70] and coxsackievirus B4 [71] via different molecular mechanisms. Besides the phenolic compounds, the analysis of the mass spectrometry data from "aszú" and "furmint" wines revealed nine other components with proven antiviral activity, such as (E)-p-coumaric acid, 11-aminoundecanoic acid, coumarin, dehydrocostus lactone, flazin, indole-3-carbinol, melatonin, bestatin and umbelliferone. These compounds were already demonstrated by different research groups to have broad antiviral activities [72-76].

Viruses activate the immune system of the host that can further lead to inflammation [36]. The antiviral activity of the compounds described above mainly consists of the modulation of the immune response and initiating the inflammatory pathways. However, the proper balance between the pro-inflammatory and anti-inflammatory processes is required for the cells and organs to maintain their physiological functions. Thus, strictly regulated pro- and anti-inflammatory pathways are necessary for the homeostasis of the cells and tissues [77]. By database search and literature mining, we could identify 20 molecules in the "aszú" and "furmint" wine samples with anti-inflammatory activity (Table S4). From the 20 identified anti-inflammatory molecules, eight phenolic compounds, rhododendrin, caffeic acid, ethyl caffeate, chlorogenic acid, ethyl gallate, fertaric acid, quercetin and taxifolin were identified. Their anti-inflammatory effects involve the inhibition of toll-like receptor 4 and toll-like receptor 7 mediated signal transduction pathways [78,79], suppression of the NF-kB pathway [80-86], downregulation of COX-2 expression [87], a decrease in the level of inflammatory cytokines such as IL-1 $\beta$, IL-6, IL-8, TNF- $\alpha$ and INF- $\gamma$ [88-90], and reduced NO production [91]. In addition to phenolic components, tetrahydroharman-3-carboxylic acid, achalensolide, (E)-p-coumaric acid, zedoarondiol, asperlin, 9S, 13R-12-oxophytodienoic acid, dehydrocostus lactone, eicosapentaenoic acid, 
indole-3-carbinol, kynurenic acid, melatonin, and umbelliferone were also identified as molecules with anti-inflammatory activity. It is interesting to note that many of the compounds, such as umbelliferone, indole-3-carbinol, and melatonin, have both antiviral and anti-inflammatory activities at the same time, reflecting a complex mechanism of action [92-95].

Viral infections, inappropriate functioning of the immune system and other factors can lead the development of tumors [96]. The altered signaling pathways can lead to the dysregulation of the cell cycle and if the suppressor processes cannot work properly the cells lose their control on the replication machinery. Therefore, a strict anti-oncogenic regulation is required for the maintenance of the normal cell cycle [97]. From the 288 molecules identified in this study, 26 compounds have anticancer activity. Among these molecules, seven phenolic molecules were identified. Dimethylcaffeic acid can increase the level of polyamines in rats having an antitumor effect since the reduction in the level of polyamines is associated with cancer growth [98]. (E)-ethyl caffeate shows cytotoxicity against the different cancer cell lines [48], while ethyl gallate can promote apoptotic cell death $[99,100]$. Taxifolin can modulate the Nrf2 and Wnt/ $\beta$-catenin cascade [101], can inhibit the proliferation of different cancer cell types [102], can initiate cell cycle arrest [103], and can activate apoptosis in prostate carcinoma cells [104]. Caffeic acid has anticancer activity against human cell lines originating from breast cancer [105,106], cervical cancer [106], metastatic cervical cancer [107], hepatocellular carcinoma [48], lung cancer, colon carcinoma [108], melanoma [109], oral squamous cell carcinoma [110], gastric cancer [111] and can suppress the UVB-induced skin carcinogenesis [112]. Besides antiviral, anti-inflammatory activities, quercetin also has anticancer activity against human cell lines originating from various cancer types [113-124], while chlorogenic acid is also a potent anticancer molecule with activity against human cell lines originating from different cancers [125-129]. We have also identified (E)-p-coumaric acid, 16-heptadecyne-1,2,4-triol, asperlin, 9S,13R-12-oxophytodienoic acid, coumarin, cyclo(phenylalanyl-prolyl), dehydrocostus lactone, DL-alanyl-DL-phenylalanine, dodecanedioic acid, eicosapentaenoic acid, indole-3-carbinol, sphinganine, L-histidinol, linamarin, melatonin, perlolyrine, phytosphingosine, pyridoxal and umbelliferone as molecules with proven anticancer activity.

The comprehensive collection of the biological functions of the identified wine components can provide a rich dataset to design in vitro and in vivo studies in order to test the beneficial effects of the different compounds. The data generated in this study can be used to design targeted examinations.

Validation of the wine components with health beneficial effects can provide high quality wines as functional food in the future. This can be especially important in case of many polyphenols such as quercetin, chlorogenic acid, caffeic acid, etc., which are insoluble in water but are soluble in alcoholic solutions. The alcohol content of wine helps the solvation of water insoluble polyphenols making wine a complex mixture of both water soluble and insoluble compounds such as phenolic compounds, acids, lipids, amino acids and other biologically active molecules [7]. The rich composition and the identified molecules with beneficial health effects highlight the potential of wine as a functional food [12].

\section{Materials and Methods}

\subsection{Wine Samples}

In this study, 12 wine samples from Tokaj Hegyalja region (Northeastern Hungary) were examined. Seven "furmint" and 5 "aszú" wines from 4 different wineries (winery 1: 2 "aszú" and 7 "furmint" samples, winery 2: 1 "aszú" and 1 "furmint" sample, winery 3: 1 "aszú" and 1 "furmint" sample, winery 4: 1 "aszú" sample) were subjected to analysis. The results of the routine chemical analysis according to Winsscan FTIR analysis (Foss Analytical A/S-HillerØd, Denmark) were listed in Table S6.

\subsection{LC-MS Analysis}

Prior to mass spectrometry analysis the components of the wines were separated using a Transcend II TLX-1 UPLC system (Thermo Scientific, Palo Alto, CA, USA) in LX mode. Chromatographic separations were performed on a TFS Hypersil gold reverse phase analytical column $(50 \times 2.1 \mathrm{~mm}$, 
$1.9 \mu \mathrm{m}$ particle size, $175 \AA$ pore size, Thermo Scientific) using a 5 min water/acetonitrile gradient. The first step of the separation was a $25 \mathrm{~s}$ equilibration with $100 \%$ buffer A followed by the increase in solvent B to $30 \%$ during $5 \mathrm{~s}$. Solvent B was further increased to $50 \%$ in $70 \mathrm{~s}$ and then increased to $95 \%$ in $60 \mathrm{~s}$ followed by a $60 \mathrm{~s}$ hold-on. In the last steps, the solvent condition was changed to $100 \% \mathrm{~A}$ in $30 \mathrm{~s}$ followed by the equilibration of the system with $100 \%$ solvent A. The flow rate was set to $0.8 \mathrm{~mL} / \mathrm{min}$. Solvent A was $0.1 \%$ formic acid in LC grade water (VWR Ltd., Radnor, PA, USA) and solvent B was $0.1 \%$ formic acid in LC grade acetonitrile (VWR Ltd.). The $100 \mu \mathrm{L}$ samples were injected in duplicates.

Mass spectrometry analyses were performed on an Orbitrap Fusion tribrid mass spectrometer (Thermo Scientific) using data-dependent acquisition. Survey scans were taken in the Orbitrap mass analyzer with 120,000 mass resolution scanning a 100-1000 $\mathrm{m} / \mathrm{z}$ range in profile mode. The AGC target was set to $4.0 \times 10^{5}$. MS/MS spectra also were acquired in the Orbitrap mass analyzer by the fragmentation of the selected parent ions using HCD dissociation with $40 \%$ collision energy. However, MS/MS spectra were recorded in centroid mode at resolution and AGC target set to 50,000 and $5.0 \times 10^{4}$, respectively. The cycle time of the analyses was $0.6 \mathrm{~s}$. Spectra were acquired in both positive and negative polarity modes. The mass spectrometry data are available at the MassIVE database (ftp://MSV000085599@massive.ucsd.edu).

\subsection{Data Analysis and Compound Identification}

The acquired data were subjected to metabolite identification using the Compound Discoverer 3.1 software (Thermo Scientific). Both positive and negative polarity mode data were loaded for the analysis. For compound detection, the mass tolerance was set to $5 \mathrm{ppm}$, the intensity tolerance was $30 \%$, the signal/noise ratio threshold was set to 3 and the minimum peak intensity was set to 100,000 cps. For the detection of compounds, $\{\mathrm{M}+\mathrm{H}]^{+},[\mathrm{M}+\mathrm{Na}]^{+},[\mathrm{M}+\mathrm{K}]^{+}$and $[\mathrm{M}-\mathrm{H}]^{-}$ions were used. The grouping of the compounds was done with $5 \mathrm{ppm}$ mass tolerance and $0.2 \mathrm{~min}$ retention time tolerance. The acquired MS2 spectra were searched against three different databases implemented into the Compound Discoverer for compound identification. The first database was the $\mathrm{m} / \mathrm{z}$ cloud [130], the autoprocessed and reference libraries were used for the identification of small molecules. Besides the $m / z$ cloud, the Chemspider database [131] was also used for identification. In the Chemspider, we used the Carotenoids database [132], FooDB [133], KEGG [134], LipidMAPS [135], Peptides [136], Phenol explorer [137], Plantcyc database [138] and the Yeast metabolome database [139]. The mass list library of the Compound Discoverer software was also used for compound identification. From the library, the Flavonoid structure database and the Endogenous metabolites database was selected for the search. The spectra of the identified molecules were analyzed manually and the hits were curated using the FISh scoring algorithm. For FISh scoring, the high mass accuracy tolerance was set to $2.5 \mathrm{Da}$ while the low accuracy mass tolerance was $0.5 \mathrm{Da}$ and the signal/noise threshold ratio was 3. The best hits were selected as compound annotations. Besides the identification, the comparative analysis of "aszú" and "furmint" wine types was also performed with the help of the software.

The peak areas were normalized by the software using constant mean normalization. For relative quantification the mean normalized peak areas were compared between the two studied groups. Principal component analysis implemented into the Compound Discoverer software was used considering the normalized peak areas. For heat map construction, normalized peak areas were used and the scaling was done before the clustering. The distance function was set to Euclidean and the linkage method was set to complete. For quantitative comparison of the "aszú" and "furmint" samples molecules with $\pm 1 \log 2$ fold change were accepted, and the significance threshold was set to $p<0.05$.

\subsection{Annotation of the Identified Compounds}

In order to obtain information about the biological and pharmacological properties of the identified compounds, an in silico approach was implemented utilizing several in-house developed bash scripts to access ChemSpider, PubChem [140,141], and PubMed [142] databases via their programmatic web services. Based on the chemical names, first the ChemSpiderIDs, and SMILES identifiers were retrieved. 
SMILES strings were then included in PUG-REST web service [143] requests to access PubChem's BioAssays [144] records and PubChem compound identifiers (CID) of each identified molecules. The retrieved CIDs were used to collect annotation data for each compound in the PubChem PUG-View interface [145]. CIDs were also used to collect literature metadata from PubMed by searching for PubMed IDs linked to the retrieved CIDs. The listed article titles, abstracts and BioAssays records were screened for specific keywords related to anti-inflammatory, antiviral and anticancer effects.

Supplementary Materials: The following are available online at http://www.mdpi.com/1422-0067/21/24/9547/s1, Table S1: List of the compounds identified in "aszú" and "furmint" wines. The novel and previously annotated components identified in wine are highlighted in bold and italics, while the novel compounds without annotation are highlighted in bold, Table S2: Compound annotation based on the PubChem BioAssay database, Table S3: Compound annotation based on the PUG-View database, Table S4: Identified wine compounds with antiviral, anti-inflammatory and anticancer activity based on the BioAssay database and literature mining, Table S5: Compounds with significantly different levels in "aszú" and "furmint" wines, Table S6: Routine chemical analysis of the examined wines according to Winsscan FTIR analysis (Foss Analytical A/S-HillerØd, Denmark).

Author Contributions: Conceptualization, J.T., Z.G. and Z.S.; methodology, G.K. and B.K.; software, G.K. and B.K.; resources, É.C., Z.G. and J.T.; data curation, G.K. and B.K.; writing-original draft preparation, G.K., B.K.; writing-review and editing, É.C., and J.T.; visualization, G.K., B.K., É.C.; supervision, É.C. and J.T. All authors have read and agreed to the published version of the manuscript.

Funding: This research was supported by the Wine Academy of Mád 1206/2018(IV.5.) and GINOP-2.3.3-15-201600020 funding.

Acknowledgments: The technical help of Renáta Kovács and Andrea Guba is greatly acknowledged. We thank Károly Vékey for reading and critically reviewing the manuscript.

Conflicts of Interest: The authors declare no conflict of interest.

\section{Abbreviations}

$\begin{array}{ll}\text { UNESCO } & \text { United Nations Educational, Scientific and Cultural Organization } \\ \text { NMR } & \text { Nuclear magnetic resonance } \\ \text { GC-MS } & \text { Gas chromatography-mass spectrometry } \\ \text { LC-MS } & \text { Liquid chromatography-mass spectrometry } \\ \text { MS/MS } & \text { Tandem mass spectrometry } \\ \text { FDA } & \text { Food and Drug Administration } \\ \text { LC-MS/MS } & \text { Liquid chromatography-tandem mass spectrometry } \\ \text { SARS-CoV } & \text { Severe acute respiratory syndrome coronavirus 2 } \\ \text { COX-2 } & \text { Cyclooxygenase-2 } \\ \text { NF-kB } & \text { Nuclear factor-kB } \\ \text { IL-1 } \beta & \text { Interleukin-1 } \beta \\ \text { IL-6 } & \text { Interleukin-6 } \\ \text { IL-8 } & \text { Interleunik-8 } \\ \text { TNF- } \alpha & \text { Tumor necrosis factor } \alpha \\ \text { INF- } \gamma & \text { Interferon } \gamma \\ \text { NO } & \text { Nitrogen monoxide } \\ \text { Nrf2 } & \text { Nuclear factor erythroid 2-related factor } 2 \\ \text { CID } & \text { PubChem compound identifier }\end{array}$

\section{References}

1. Wu, C.D. Grape Products and Oral Health. J. Nutr. 2009, 139, 1818S-1823S. [CrossRef] [PubMed]

2. Weseler, A.R.; Bast, A. Masquelier's grape seed extract: From basic flavonoid research to a well-characterized food supplement with health benefits. Nutr. J. 2017, 16, 5. [CrossRef] [PubMed]

3. Nirmala, J.G.; Narendhirakannan, R.T. Vitis vinifera peel and seed gold nanoparticles exhibit chemopreventive potential, antioxidant activity and induce apoptosis through mutant p53, Bcl-2 and pan cytokeratin down-regulation in experimental animals. Biomed. Pharmacother. 2017, 89, 902-917. [CrossRef] [PubMed]

4. Zunino, S.J. Type 2 Diabetes and Glycemic Response to Grapes or Grape Products. J. Nutr. 2009, 139, 1794S-1800S. [CrossRef] 
5. Rasines-Perea, Z.; Teissedre, P.L. Grape Polyphenols' effects in human cardiovascular diseases and diabetes. Molecules 2017, 22, 68. [CrossRef]

6. Baiano, A.; Scrocco, C.; Sepielli, G.; Del Nobile, M.A. Wine Processing: A Critical Review of Physical, Chemical, and Sensory Implications of Innovative Vinification Procedures. Crit. Rev. Food Sci. Nutr. 2016, 56, 2391-2407. [CrossRef]

7. Diamantidou, D.; Zotou, A.; Theodoridis, G. Wine and grape marc spirits metabolomics. Metabolomics 2018, 14, 159. [CrossRef]

8. Zaukuu, J.L.Z.; Soós, J.; Bodor, Z.; Felföldi, J.; Magyar, I.; Kovacs, Z. Authentication of Tokaj Wine (Hungaricum) with the Electronic Tongue and Near Infrared Spectroscopy. J. Food Sci. 2019, 84, 3437-3444. [CrossRef]

9. Bodor, P.; Szoke, A.; Toth-Lencses, K.; Veres, A.; Deak, T.; Kozma, P.; Bisztray, G.D.; Kiss, E. Differentiation of grapevine (Vitis vinifera L.) conculta members based on molecular tools. Biotechnol. Biotechnol. Equip. 2014, 28, 14-20. [CrossRef]

10. Magyar, I.; Soós, J. Botrytized wines-Current perspectives. Int. J. Wine Res. 2016, 8, 29-39. [CrossRef]

11. Magyar, I. Botrytized wines. In Advances in Food and Nutrition Research; Academic Press Inc.: Cambridge, MA, USA, 2011; Volume 63, pp. 147-206.

12. Yoo, Y.J.; Saliba, A.J.; Prenzler, P.D. Should Red Wine Be Considered a Functional Food? Compr. Rev. Food Sci. Food Saf. 2010, 9, 530-551. [CrossRef]

13. Haseeb, S.; Alexander, B.; Baranchuk, A. Wine and Cardiovascular Health. Circulation 2017, 136, 1434-1448. [CrossRef] [PubMed]

14. Castaldo, L.; Narváez, A.; Izzo, L.; Graziani, G.; Gaspari, A.; Di Minno, G.; Ritieni, A. Red wine consumption and cardiovascular health. Molecules 2019, 24, 3626. [CrossRef] [PubMed]

15. Rodrigo, R.; Miranda, A.; Vergara, L. Modulation of endogenous antioxidant system by wine polyphenols in human disease. Clin. Chim. Acta 2011, 412, 410-424. [CrossRef]

16. Cueva, C.; Gil-Sánchez, I.; Ayuda-Durán, B.; González-Manzano, S.; González-Paramás, A.M.; Santos-Buelga, C.; Bartolomé, B.; Moreno-Arribas, M.V. An Integrated View of the Effects of Wine Polyphenols and Their Relevant Metabolites on Gut and Host Health. Molecules 2017, 22, 99. [CrossRef]

17. Fernandes, I.; Pérez-Gregorio, R.; Soares, S.; Mateus, N.; De Freitas, V.; Santos-Buelga, C.; Feliciano, A.S. Wine flavonoids in health and disease prevention. Molecules 2017, 22, 292. [CrossRef]

18. Hong, Y.S. NMR-based metabolomics in wine science. Magn. Reson. Chem. 2011, 49, S13-S21. [CrossRef]

19. Amargianitaki, M.; Spyros, A. NMR-based metabolomics in wine quality control and authentication. Chem. Biol. Technol. Agric. 2017, 4, 9. [CrossRef]

20. Fournié-Zaluski, M.C.; Soroca-Lucas, E.; Roques, B.P.; Chaillet, P.; Margais-Collado, H.; Costentin, J. New Carboxyalkyl Inhibitors of Brain Enkephalinase: Synthesis, Biological Activity, and Analgesic Properties. J. Med. Chem. 1983, 26, 60-65. [CrossRef]

21. National Center for Biotechnology Information. PubChem Database. Available online: https://pubchem.ncbi. nlm.nih.gov/bioassay/1565\#sid=7978036 (accessed on 5 May 2020).

22. Glennon, R.A.; Liebowitz, S.M. Serotonin Receptor Affinity of Cathinone and Related Analogues. J. Med. Chem. 1982, 25, 393-397. [CrossRef]

23. Glennon, R.A.; Liebowitz, S.M.; Anderson, G.M. Serotonin Receptor Affinities of Psychoactive Phenalkylamine Analogues. J. Med. Chem. 1980, 23, 294-299. [CrossRef] [PubMed]

24. Rahnasto, M.; Raunio, H.; Poso, A.; Wittekindt, C.; Juvonen, R.O. Quantitative structure-activity relationship analysis of inhibitors of the nicotine metabolizing CYP2A6 enzyme. J. Med. Chem. 2005, 48, 440-449. [CrossRef] [PubMed]

25. Lewin, A.H.; Navarro, H.A.; Wayne Mascarella, S. Structure-activity correlations for $\beta$-phenethylamines at human trace amine receptor 1. Bioorg. Med. Chem. 2008, 16, 7415-7423. [CrossRef] [PubMed]

26. National Center for Biotechnology Information. PubChem Database. Source=The Scripps Research Institute Molecular Screening Center, AID=793. Available online: https:/pubchem.ncbi.nlm.nih.gov/bioassay/793 (accessed on 5 May 2020).

27. National Center for Biotechnology Information. PubChem Database. Source=The Scripps Research Institute Molecular Screening Center, AID=1040. Available online: https://pubchem.ncbi.nlm.nih.gov/bioassay/1040 (accessed on 5 May 2020). 
28. National Center for Biotechnology Information. PubChem Database. Source=1043, AID=1159608. Available online: https://pubchem.ncbi.nlm.nih.gov/bioassay/1159608 (accessed on 5 May 2020).

29. National Center for Biotechnology Information. PubChem Database. Source=NCGC, AID=938. Available online: https://pubchem.ncbi.nlm.nih.gov/bioassay/938 (accessed on 5 May 2020).

30. National Center for Biotechnology Information. PubChem Database. Source=NCGC, AID=893. Available online: https://pubchem.ncbi.nlm.nih.gov/bioassay/893 (accessed on 5 May 2020).

31. Aung, H.T.; Furukawa, T.; Nikai, T.; Niwa, M.; Takaya, Y. Contribution of cinnamic acid analogues in rosmarinic acid to inhibition of snake venom induced hemorrhage. Bioorg. Med. Chem. 2011, 19, 2392-2396. [CrossRef]

32. Bagnardi, V.; Rota, M.; Botteri, E.; Tramacere, I.; Islami, F.; Fedirko, V.; Scotti, L.; Jenab, M.; Turati, F.; Pasquali, E.; et al. Alcohol consumption and site-specific cancer risk: A comprehensive dose-response meta-analysis. Br. J. Cancer 2015, 112, 580-593. [CrossRef]

33. Piano, M.R. Alcohol's Effects on the Cardiovascular System. Alcohol Res. 2017, 38, $219-241$.

34. Pandey, K.B.; Rizvi, S.I. Plant polyphenols as dietary antioxidants in human health and disease. Oxid. Med. Cell. Longev. 2009, 2, 270-278. [CrossRef]

35. Kennedy, J.A.; Matthews, M.A.; Waterhouse, A.L. Effect of Maturity and Vine Water Status on Grape Skin and Wine Flavonoids. Am. J. Enol. Vitic. 2002, 53, 268-274.

36. Bavinger, J.C.; Shantha, J.G.; Yeh, S. Ebola, COVID-19, and emerging infectious disease: Lessons learned and future preparedness. Curr. Opin. Ophthalmol. 2020, 31, 416-422. [CrossRef]

37. Lin, L.T.; Hsu, W.C.; Lin, C.C. Antiviral natural products and herbal medicines. J. Tradit. Complement. Med. 2014, 4, 24-35. [CrossRef]

38. Konowalchuk, J.; Speirs, J.I. Antiviral activity of fruit extracts. J. Food Sci. 1976, 41, 1013-1017. [CrossRef]

39. Nikolaeva-Glomb, L.; Mukova, L.; Nikolova, N.; Badjakov, I.; Dincheva, I.; Kondakova, V.; Doumanova, L.; Galabov, A.S. In vitro antiviral activity of a series of wild berry fruit extracts against representatives of Picorna-, Orthomyxo- and Paramyxoviridae. Nat. Prod. Commun. 2014, 9, 51-54. [CrossRef] [PubMed]

40. Danaher, R.J.; Wang, C.; Dai, J.; Mumper, R.J.; Miller, C.S. Antiviral effects of blackberry extract against herpes simplex virus type 1. Oral Surg. Oral Med. Oral Pathol. Oral Radiol. Endodontol. 2011, 112, e31-e35. [CrossRef]

41. Wang, R.R.; Gu, Q.; Wang, Y.H.; Zhang, X.M.; Yang, L.M.; Zhou, J.; Chen, J.J.; Zheng, Y.T. Anti-HIV-1 activities of compounds isolated from the medicinal plant Rhus chinensis. J. Ethnopharmacol. 2008, 117, 249-256. [CrossRef] [PubMed]

42. Byung, S.M.; Hyeong, K.L.; Sang, M.L.; Young, H.K.; Ki, H.B.; Otake, T.; Nakamura, N.; Hattori, M. Anti-human immunodeficiency virus-type 1 activity of constituents from Juglans mandshurica. Arch. Pharm. Res. 2002, 25, 441-445. [CrossRef]

43. Pu, J.X.; Yang, L.M.; Xiao, W.L.; Li, R.T.; Lei, C.; Gao, X.M.; Huang, S.X.; Li, S.H.; Zheng, Y.T.; Huang, H.; et al. Compounds from Kadsura heteroclita and related anti-HIV activity. Phytochemistry 2008, 69, 1266-1272. [CrossRef]

44. Yang, X.; Zhu, X.; Ji, H.; Deng, J.; Lu, P.; Jiang, Z.; Li, X.; Wang, Y.; Wang, C.; Zhao, J.; et al. Quercetin synergistically reactivates human immunodeficiency virus type 1 latency by activating nuclear factor-кB. Mol. Med. Rep. 2018, 17, 2501-2508. [CrossRef]

45. Mahmood, N.; Piacente, S.; Pizza, C.; Burke, A.; Khan, A.I.; Hayt, A.J. The anti-HIV activity and mechanisms of action of pure compounds isolated from Rosa damascena. Biochem. Biophys. Res. Commun. 1996, 229, 73-79. [CrossRef]

46. Esposito, F.; Sanna, C.; Del Vecchio, C.; Cannas, V.; Venditti, A.; Corona, A.; Bianco, A.; Serrilli, A.M.; Guarcini, L.; Parolin, C.; et al. Hypericum hircinum L. components as new single-molecule inhibitors of both HIV-1 reverse transcriptase-associated DNA polymerase and ribonuclease H activities. Pathog. Dis. 2013, 68, 116-124. [CrossRef]

47. Tamura, H.; Akioka, T.; Ueno, K.; Chujyo, T.; Okazaki, K.; King, P.J.; Robinson, W.E. Anti-human immunodeficiency virus activity of 3,4,5-tricaffeoylquinic acid in cultured cells of lettuce leaves. Mol. Nutr. Food Res. 2006, 50, 396-400. [CrossRef]

48. Xia, C.-N.; Li, H.-B.; Liu, F.; Hu, W.-X. Synthesis of trans-caffeate analogues and their bioactivities against HIV-1 integrase and cancer cell lines. Bioorg. Med. Chem. Lett. 2008, 18, 6553-6557. [CrossRef] [PubMed] 
49. Biziagos, E.; Crance, J.-M.; Passagot, J.; Deloince, R. Effect of antiviral substances on hepatitis A virus replication in vitro. J. Med. Virol. 1987, 22, 57-66. [CrossRef] [PubMed]

50. Khachatoorian, R.; Arumugaswami, V.; Raychaudhuri, S.; Yeh, G.K.; Maloney, E.M.; Wang, J.; Dasgupta, A.; French, S.W. Divergent antiviral effects of bioflavonoids on the hepatitis C virus life cycle. Virology 2012, 433, 346-355. [CrossRef] [PubMed]

51. Cheng, Z.; Sun, G.; Guo, W.; Huang, Y.; Sun, W.; Zhao, F.; Hu, K. Inhibition of hepatitis B virus replication by quercetin in human hepatoma cell lines. Virol. Sin. 2015, 30, 261-268. [CrossRef]

52. Wang, G.F.; Shi, L.P.; Ren, Y.D.; Liu, Q.F.; Liu, H.F.; Zhang, R.J.; Li, Z.; Zhu, F.H.; He, P.L.; Tang, W.; et al. Anti-hepatitis B virus activity of chlorogenic acid, quinic acid and caffeic acid in vivo and in vitro. Antivir. Res. 2009, 83, 186-190. [CrossRef]

53. Shen, H.; Yamashita, A.; Nakakoshi, M.; Yokoe, H.; Sudo, M.; Kasai, H.; Tanaka, T.; Fujimoto, Y.; Ikeda, M.; Kato, N.; et al. Inhibitory Effects of Caffeic Acid Phenethyl Ester Derivatives on Replication of Hepatitis C Virus. PLoS ONE 2013, 8, e82299. [CrossRef]

54. Zhao, Y.; Geng, C.A.; Sun, C.L.; Ma, Y.B.; Huang, X.Y.; Cao, T.W.; He, K.; Wang, H.; Zhang, X.M.; Chen, J.J. Polyacetylenes and anti-hepatitis B virus active constituents from Artemisia capillaris. Fitoterapia 2014, 95, 187-193. [CrossRef]

55. Chen, C.; Jiang, Z.Y.; Yu, B.; Wu, X.L.; Dai, C.Q.; Zhao, C.L.; Ju, D.H.; Chen, X.Y. Study on the anti-H1N1 virus effects of quercetin and oseltamivir and their mechanism related to TLR7 pathway. J. Asian Nat. Prod. Res. 2012, 14, 877-885. [CrossRef]

56. Liu, Z.; Zhao, J.; Li, W.; Wang, X.; Xu, J.; Xie, J.; Tao, K.; Shen, L.; Zhang, R. Molecular docking of potential inhibitors for influenza H7N9. Comput. Math. Methods Med. 2015, 2015, 480764. [CrossRef]

57. Ibrahim, A.K.; Youssef, A.I.; Arafa, A.S.; Ahmed, S.A. Anti-H5N1 virus flavonoids from Capparis sinaica Veill. Nat. Prod. Res. 2013, 27, 2149-2153. [CrossRef]

58. Davis, J.M.; Murphy, E.A.; McClellan, J.L.; Carmichael, M.D.; Gangemi, J.D. Quercetin reduces susceptibility to influenza infection following stressful exercise. Am. J. Physiol. Integr. Comp. Physiol. 2008, 295, R505-R509. [CrossRef]

59. Boon, A.C.M.; Vos, A.P.; Graus, Y.M.F.; Rimmelzwaan, G.F.; Osterhaus, A.D.M.E. In vitro Effect of Bioactive Compounds on Influenza Virus Specific B- and T-Cell Responses. Scand. J. Immunol. 2002, 55, $24-32$. [CrossRef]

60. Gamaleldin Elsadig Karar, M.; Matei, M.F.; Jaiswal, R.; Illenberger, S.; Kuhnert, N. Neuraminidase inhibition of Dietary chlorogenic acids and derivatives-potential antivirals from dietary sources. Food Funct. 2016, 7, 2052-2059. [CrossRef] [PubMed]

61. Ding, Y.; Cao, Z.; Cao, L.; Ding, G.; Wang, Z.; Xiao, W. Antiviral activity of chlorogenic acid against influenza A (H1N1/H3N2) virus and its inhibition of neuraminidase. Sci. Rep. 2017, 7, 45723. [CrossRef] [PubMed]

62. Chiang, L.C.; Chiang, W.; Liu, M.C.; Lin, C.C. In vitro antiviral activities of Caesalpinia pulcherrima and its related flavonoids. J. Antimicrob. Chemother. 2003, 52, 194-198. [CrossRef] [PubMed]

63. Chiang, L.C.; Chiang, W.; Chang, M.Y.; Ng, L.T.; Lin, C.C. Antiviral activity of Plantago major extracts and related compounds in vitro. Antivir. Res. 2002, 55, 53-62. [CrossRef]

64. Guo, Y.J.; Luo, T.; Wu, F.; Mei, Y.W.; Peng, J.; Liu, H.; Li, H.R.; Zhang, S.L.; Dong, J.H.; Fang, Y.; et al. Involvement of TLR2 and TLR9 in the anti-inflammatory effects of chlorogenic acid in HSV-1-infected microglia. Life Sci. 2015, 127, 12-18. [CrossRef]

65. Kratz, J.M.; Andrighetti-Fröhner, C.R.; Kolling, D.J.; Leal, P.C.; Cirne-Santos, C.C.; Yunes, R.A.; Nunes, R.J.; Trybala, E.; Bergström, T.; Frugulhetti, I.C.P.P.; et al. Anti-HSV-1 and anti-HIV-1 activity of gallic acid and pentyl gallate. Mem. Inst. Oswaldo Cruz 2008, 103, 437-442. [CrossRef]

66. Yao, C.; Xi, C.; Hu, K.; Gao, W.; Cai, X.; Qin, J.; Lv, S.; Du, C.; Wei, Y. Inhibition of enterovirus 71 replication and viral 3C protease by quercetin. Virol. J. 2018, 15, 116. [CrossRef]

67. Li, X.; Liu, Y.; Hou, X.; Peng, H.; Zhang, L.; Jiang, Q.; Shi, M.; Ji, Y.; Wang, Y.; Shi, W. Chlorogenic Acid Inhibits the Replication and Viability of Enterovirus 71 In Vitro. PLoS ONE 2013, 8, e76007. [CrossRef]

68. Chen, L.; Li, J.; Luo, C.; Liu, H.; Xu, W.; Chen, G.; Liew, O.W.; Zhu, W.; Puah, C.M.; Shen, X.; et al. Binding interaction of quercetin-3- $\beta$-galactoside and its synthetic derivatives with SARS-CoV 3CLpro: Structure-activity relationship studies reveal salient pharmacophore features. Bioorg. Med. Chem. 2006, 14, 8295-8306. [CrossRef] [PubMed] 
69. Ganesan, S.; Faris, A.N.; Comstock, A.T.; Wang, Q.; Nanua, S.; Hershenson, M.B.; Sajjan, U.S. Quercetin inhibits rhinovirus replication in vitro and in vivo. Antivir. Res. 2012, 94, 258-271. [CrossRef] [PubMed]

70. Lee, M.; Son, M.; Ryu, E.; Shin, Y.S.; Kim, J.G.; Kang, B.W.; Cho, H.; Kang, H. Quercetin-induced apoptosis prevents EBV infection. Oncotarget 2015, 6, 12603-12624. [CrossRef] [PubMed]

71. Galochkina, A.V.; Anikin, V.B.; Babkin, V.A.; Ostrouhova, L.A.; Zarubaev, V.V. Virus-inhibiting activity of dihydroquercetin, a flavonoid from Larix sibirica, against coxsackievirus B4 in a model of viral pancreatitis. Arch. Virol. 2016, 161, 929-938. [CrossRef] [PubMed]

72. Parang, K.; Wiebe, L.I.; Knaus, E.E.; Huang, J.S.; Tyrrell, D.L.; Csizmadia, F. In vitro antiviral activities of myristic acid analogs against human immunodeficiency and hepatitis B viruses. Antivir. Res. 1997, 34, 75-90. [CrossRef]

73. Bourinbaiar, A.S.; Tan, X.; Nagorny, R. Inhibitory effect of coumarins on HIV-1 replication and cell-mediated or cell-free viral transmission. Acta Virol. 1993, 37, 241-250.

74. Chen, H.C.; Chou, C.K.; Lee, S.D.; Wang, J.C.; Yeh, S.F. Active compounds from Saussurea lappa Clarks that suppress hepatitis B virus surface antigen gene expression in human hepatoma cells. Antivir. Res. 1995, 27, 99-109. [CrossRef]

75. Wang, Y.H.; Tang, J.G.; Wang, R.R.; Yang, L.M.; Dong, Z.J.; Du, L.; Shen, X.; Liu, J.K.; Zheng, Y.T. Flazinamide, a novel $\beta$-carboline compound with anti-HIV actions. Biochem. Biophys. Res. Commun. 2007, 355, 1091-1095. [CrossRef]

76. Anderson, G.; Maes, M.; Markus, R.P.; Rodriguez, M. Ebola virus: Melatonin as a readily available treatment option. J. Med. Virol. 2015, 87, 537-543. [CrossRef]

77. Cicchese, J.M.; Evans, S.; Hult, C.; Joslyn, L.R.; Wessler, T.; Millar, J.A.; Marino, S.; Cilfone, N.A.; Mattila, J.T.; Linderman, J.J.; et al. Dynamic balance of pro- and anti-inflammatory signals controls disease and limits pathology. Immunol. Rev. 2018, 285, 147-167. [CrossRef]

78. Jeon, Y.J.; Sah, S.K.; Yang, H.S.; Lee, J.H.; Shin, J.; Kim, T.Y. Rhododendrin inhibits toll-like receptor-7-mediated psoriasis-like skin inflammation in mice. Exp. Mol. Med. 2017, 49, 349. [CrossRef] [PubMed]

79. Shi, H.; Dong, L.; Jiang, J.; Zhao, J.; Zhao, G.; Dang, X.; Lu, X.; Jia, M. Chlorogenic acid reduces liver inflammation and fibrosis through inhibition of toll-like receptor 4 signaling pathway. Toxicology 2013, 303, 107-114. [CrossRef] [PubMed]

80. Kim, A.; Nam, Y.J.; Lee, C.S. Taxifolin reduces the cholesterol oxidation product-induced neuronal apoptosis by suppressing the Akt and NF-kB activation-mediated cell death. Brain Res. Bull. 2017, 134, 63-71. [CrossRef] [PubMed]

81. Nair, M.P.; Mahajan, S.; Reynolds, J.L.; Aalinkeel, R.; Nair, H.; Schwartz, S.A.; Kandaswami, C. The flavonoid quercetin inhibits proinflammatory cytokine (tumor necrosis factor alpha) gene expression in normal peripheral blood mononuclear cells via modulation of the NF- $\kappa \beta$ system. Clin. Vaccine Immunol. 2006, 13, 319-328. [CrossRef] [PubMed]

82. Vicentini, F.T.M.C.; He, T.; Shao, Y.; Fonseca, M.J.V.; Verri, W.A.; Fisher, G.J.; Xu, Y. Quercetin inhibits UV irradiation-induced inflammatory cytokine production in primary human keratinocytes by suppressing NF-kB pathway. J. Dermatol. Sci. 2011, 61, 162-168. [CrossRef] [PubMed]

83. Murase, T.; Kume, N.; Hase, T.; Shibuya, Y.; Nishizawa, Y.; Tokimitsu, I.; Kita, T. Gallates Inhibit Cytokine-Induced Nuclear Translocation of NF-kB and Expression of Leukocyte Adhesion Molecules in Vascular Endothelial Cells. Arterioscler. Thromb. Vasc. Biol. 1999, 19, 1412-1420. [CrossRef]

84. Bang, B.W.; Park, D.; Kwon, K.S.; Lee, D.H.; Jang, M.-J.; Park, S.K.; Kim, J.-Y. BST-104, a Water Extract of Lonicera japonica, Has a Gastroprotective Effect via Antioxidant and Anti-Inflammatory Activities. J. Med. Food 2019, 22, 140-151. [CrossRef]

85. Khan, A.Q.; Khan, R.; Qamar, W.; Lateef, A.; Ali, F.; Tahir, M.; Tahir, M.; Muneeb-U-Rehman, S.S. Caffeic acid attenuates 12-O-tetradecanoyl-phorbol-13-acetate (TPA)-induced NF- $\mathrm{kB}$ and COX-2 expression in mouse skin: Abrogation of oxidative stress, inflammatory responses and proinflammatory cytokine production. Food Chem. Toxicol. 2012, 50, 175-183. [CrossRef]

86. Chiang, Y.M.; Lo, C.P.; Chen, Y.P.; Wang, S.Y.; Yang, N.S.; Kuo, Y.H.; Shyur, L.F. Ethyl caffeate suppresses NF- $\mathrm{kB}$ activation and its downstream inflammatory mediators, iNOS, COX-2, and PGE 2 in vitro or in mouse skin. Br. J. Pharmacol. 2005, 146, 352-363. [CrossRef] 
87. Amirova, K.M.; Dimitrova, P.; Marchev, A.S.; Aneva, I.Y.; Georgiev, M.I. Clinopodium vulgare L. (wild basil) extract and its active constituents modulate cyclooxygenase-2 expression in neutrophils. Food Chem. Toxicol. 2019, 124, 1-9. [CrossRef]

88. Meng, Z.Q.; Tang, Z.H.; Yan, Y.X.; Guo, C.R.; Cao, L.; Ding, G.; Huang, W.Z.; Wang, Z.Z.; Wang, K.D.G.; Xiao, W.; et al. Study on the anti-gout activity of chlorogenic acid: Improvement on hyperuricemia and gouty inflammation. Am. J. Chin. Med. 2014, 42, 1471-1483. [CrossRef] [PubMed]

89. Zhang, M.; Zhou, J.; Wang, L.; Li, B.; Guo, J.; Guan, X.; Han, Q.; Zhang, H. Caffeic Acid Reduces Cutaneous Tumor Necrosis Factor Alpha (TNF- $\alpha$ ), IL-6 and IL-1 $\beta$ Levels and Ameliorates Skin Edema in Acute and Chronic Model of Cutaneous Inflammation in Mice. Biol. Pharm. Bull. 2014, 37, 347-354. [CrossRef] [PubMed]

90. Guerriero, E.; Sorice, A.; Capone, F.; Costantini, S.; Palladino, P.; D'ischia, M.; Castello, G. Effects of Lipoic Acid, Caffeic Acid and a Synthesized Lipoyl-Caffeic Conjugate on Human Hepatoma Cell Lines. Molecules 2011, 16, 6365-6377. [CrossRef] [PubMed]

91. Hwang, S.J.; Kim, Y.W.; Park, Y.; Lee, H.J.; Kim, K.W. Anti-inflammatory effects of chlorogenic acid in lipopolysaccharide- stimulated RAW 264.7 cells. Inflamm. Res. 2014, 63, 81-90. [CrossRef]

92. Kurokawa, M.; Watanabe, W.; Shimizu, T.; Sawamura, R.; Shiraki, K. Modulation of cytokine production by 7-hydroxycoumarin in vitro and its efficacy against influenza infection in mice. Antivir. Res. 2010, 85, 373-380. [CrossRef]

93. Kabel, A.M.; Al-Shehri, A.H.; Al-Talhi, R.A.; Abd Elmaaboud, M.A. The promising effect of linagliptin and/or indole-3-carbinol on experimentally-induced polycystic ovarian syndrome. Chem. Biol. Interact. 2017, 273, 190-199. [CrossRef]

94. Zhang, R.; Wang, X.; Ni, L.; Di, X.; Ma, B.; Niu, S.; Liu, C.; Reiter, R.J. COVID-19: Melatonin as a potential adjuvant treatment. Life Sci. 2020, 250, 117583. [CrossRef]

95. Alamili, M.; Bendtzen, K.; Lykkesfeldt, J.; Rosenberg, J.; Gögenur, I. Melatonin suppresses markers of inflammation and oxidative damage in a human daytime endotoxemia model. J. Crit. Care 2014, 29, 184.e9-184.e13. [CrossRef]

96. Coussens, L.M.; Werb, Z. Inflammation and cancer. Nature 2002, 420, 860-867. [CrossRef]

97. Zhang, J.; Chen, Y.H.; Lu, Q. Pro-oncogenic and anti-oncogenic pathways: Opportunities and challenges of cancer therapy. Future Oncol. 2010, 6, 587-603. [CrossRef]

98. Watanabe, S.; Sato, S.; Nagase, S.; Shimosato, K.; Saito, T. Polyamine levels in various tissues of rats treated with 3-hydroxy-4-methoxycinnamic acid and 3,4-dimethoxycinnamic acid. Anticancer Drugs 1996, 7, 866-872. [CrossRef] [PubMed]

99. Saleem, A.; Husheem, M.; Härkönen, P.; Pihlaja, K. Inhibition of cancer cell growth by crude extract and the phenolics of Terminalia chebula retz. fruit. J. Ethnopharmacol. 2002, 81, 327-336. [CrossRef]

100. Kim, W.H.; Song, H.O.; Choi, H.J.; Bang, H.I.; Choi, D.Y.; Park, H. Ethyl gallate induces apoptosis of HL-60 cells by promoting the expression of caspases-8, $-9,-3$, apoptosis-inducing factor and endonuclease G. Int. J. Mol. Sci. 2012, 13, 11912-11922. [CrossRef]

101. Manigandan, K.; Manimaran, D.; Jayaraj, R.L.; Elangovan, N.; Dhivya, V.; Kaphle, A. Taxifolin curbs NF-kB-mediated Wnt/ $\beta$-catenin signaling via up-regulating Nrf2 pathway in experimental colon carcinogenesis. Biochimie 2015, 119, 103-112. [CrossRef] [PubMed]

102. Razak, S.; Afsar, T.; Ullah, A.; Almajwal, A.; Alkholief, M.; Alshamsan, A.; Jahan, S. Taxifolin, a natural flavonoid interacts with cell cycle regulators causes cell cycle arrest and causes tumor regression by activating Wnt/ $\beta$-catenin signaling pathway 06 Biological Sciences 0601 Biochemistry and Cell Biology 11 Medical and Health Sciences 1112 Oncology and Carcinogenesis. BMC Cancer 2018, 18. [CrossRef]

103. Zhou, W.; Liu, Z.; Wang, M.; Chen, D.; Zhou, L.; Guo, L. Taxifolin inhibits the development of scar cell carcinoma by inducing apoptosis, cell cycle arrest, and suppression of PI3K/ AKT/mTOR pathway. J. BUON 2019, 24, 853-858.

104. Zhang, Z.R.; Al Zaharna, M.; Wong, M.M.K.; Chiu, S.K.; Cheung, H.Y. Taxifolin Enhances Andrographolide-Induced Mitotic Arrest and Apoptosis in Human Prostate Cancer Cells via Spindle Assembly Checkpoint Activation. PLoS ONE 2013, 8, e54577. [CrossRef]

105. Kabala-Dzik, A.; Rzepecka-Stojko, A.; Kubina, R.; Jastrzȩbska-Stojko, Ż.; Stojko, R.; Wojtyczka, R.D.; Stojko, J. Migration rate inhibition of breast cancer cells treated by caffeic acid and caffeic acid phenethyl ester: An in vitro comparison study. Nutrients 2017, 9, 1144. [CrossRef] 
106. Viveros-Valdez, E.; Rivas-Morales, C.; Oranday-Cárdenas, A.; Castro-Garza, J.; Carranza-Rosales, P. Antiproliferative effect from the Mexican Poleo (Hedeoma drummondii). J. Med. Food 2010, 13, 740-742. [CrossRef]

107. Tyszka-Czochara, M.; Bukowska-Strakova, K.; Majka, M. Metformin and caffeic acid regulate metabolic reprogramming in human cervical carcinoma $\mathrm{SiHa/HTB-35}$ cells and augment anticancer activity of Cisplatin via cell cycle regulation. Food Chem. Toxicol. 2017, 106, 260-272. [CrossRef]

108. Nasr Bouzaiene, N.; Kilani Jaziri, S.; Kovacic, H.; Chekir-Ghedira, L.; Ghedira, K.; Luis, J. The effects of caffeic, coumaric and ferulic acids on proliferation, superoxide production, adhesion and migration of human tumor cells in vitro. Eur. J. Pharmacol. 2015, 766, 99-105. [CrossRef] [PubMed]

109. Jaganathan, S.K. Growth inhibition by caffeic acid, one of the phenolic constituents of honey, in HCT 15 colon cancer cells. Sci. World J. 2012, 2012, 372345. [CrossRef] [PubMed]

110. Pelinson, L.P.; Assmann, C.E.; Palma, T.V.; da Cruz, I.B.M.; Pillat, M.M.; Mânica, A.; Stefanello, N.; Weis, G.C.C.; de Oliveira Alves, A.; de Andrade, C.M.; et al. Antiproliferative and apoptotic effects of caffeic acid on SK-Mel-28 human melanoma cancer cells. Mol. Biol. Rep. 2019, 46, 2085-2092. [CrossRef] [PubMed]

111. Dziedzic, A.; Kubina, R.; Kabała-Dzik, A.; Wojtyczka, R.D.; Morawiec, T.; Bułdak, R.J. Caffeic acid reduces the viability and migration rate of oral carcinoma cells (SCC-25) exposed to low concentrations of ethanol. Int. J. Mol. Sci. 2014, 15, 18725-18741. [CrossRef] [PubMed]

112. Chang, H.T.; Chen, I.L.; Chou, C.T.; Liang, W.Z.; Kuo, D.H.; Shieh, P.; Jan, C.R. Effect of caffeic acid on $\mathrm{Ca}^{2+}$ homeostasis and apoptosis in SCM1 human gastric cancer cells. Arch. Toxicol. 2013, 87, 2141-2150. [CrossRef] [PubMed]

113. Kang, N.J.; Lee, K.W.; Shin, B.J.; Jung, S.K.; Hwang, M.K.; Bode, A.M.; Heo, Y.S.; Lee, H.J.; Dong, Z. Caffeic acid, a phenolic phytochemical in coffee, directly inhibits Fyn kinase activity and UVB-induced COX-2 expression. Carcinogenesis 2009, 30, 321-330. [CrossRef]

114. Lee, Y.K.; Hwang, J.T.; Kwon, D.Y.; Surh, Y.J.; Park, O.J. Induction of apoptosis by quercetin is mediated through AMPK $\alpha 1 /$ ASK1/p38 pathway. Cancer Lett. 2010, 292, 228-236. [CrossRef]

115. Ranelletti, F.O.; Maggiano, N.; Serra, F.G.; Ricci, R.; Larocca, L.M.; Lanza, P.; Scambia, G.; Fattorossi, A.; Capelli, A.; Piantelli, M. Quercetin inhibits p21-ras expression in human colon cancer cell lines and in primary colorectal tumors. Int. J. Cancer 2000, 85, 438-445. [CrossRef]

116. Yang, Y.M.; Son, Y.O.; Lee, S.A.; Jeon, Y.M.; Lee, J.C. Quercetin inhibits $\alpha$-MSH-stimulated melanogenesis in B16F10 melanoma cells. Phyther. Res. 2011, 25, 1166-1173. [CrossRef]

117. Siegelin, M.D.; Reuss, D.E.; Habel, A.; Rami, A.; Von Deimling, A. Quercetin promotes degradation of survivin and thereby enhances death-receptor- mediated apoptosis in glioma cells. Neuro Oncol. 2009, 11, 122-131. [CrossRef]

118. Lu, J.; Papp, L.V.; Fang, J.; Rodriguez-Nieto, S.; Zhivotovsky, B.; Holmgren, A. Inhibition of mammalian thioredoxin reductase by some flavonoids: Implications for myricetin and quercetin anticancer activity. Cancer Res. 2006, 66, 4410-4418. [CrossRef] [PubMed]

119. Zhang, Q.; Zhao, X.H.; Wang, Z.J. Flavones and flavonols exert cytotoxic effects on a human oesophageal adenocarcinoma cell line (OE33) by causing G2/M arrest and inducing apoptosis. Food Chem. Toxicol. 2008, 46, 2042-2053. [CrossRef] [PubMed]

120. Jung, J.H.; Lee, J.O.; Kim, J.H.; Lee, S.K.; You, G.Y.; Park, S.H.; Park, J.M.; Kim, E.K.; Suh, P.G.; An, J.K.; et al. Quercetin suppresses HeLa cell viability via AMPK-induced HSP70 and EGFR down-regulation. J. Cell. Physiol. 2010, 223, 408-414. [CrossRef]

121. Haghiac, M.; Walle, T. Quercetin induces necrosis and apoptosis in SCC-9 oral cancer cells. Nutr. Cancer 2005, 53, 220-231. [CrossRef]

122. Mu, C.; Jia, P.; Yan, Z.; Liu, X.; Li, X.; Liu, H. Quercetin induces cell cycle G1 arrest through elevating Cdk inhibitors p21 and p27 in human hepatoma cell line (HepG2). Methods Find. Exp. Clin. Pharmacol. 2007, 29, 179-183. [CrossRef] [PubMed]

123. Monasterio, A.; Urdaci, M.C.; Pinchuk, I.V.; López-Moratalla, N.; Martínez-Irujo, J.J. Flavonoids induce apoptosis in human leukemia U937 cells through caspase- and caspase-calpain-dependent pathways. Nutr. Cancer 2004, 50, 90-100. [CrossRef]

124. Liang, W.; Li, X.; Li, C.; Liao, L.; Gao, B.; Gan, H.; Yang, Z.; Liao, L.; Chen, X. Quercetin-mediated apoptosis via activation of the mitochondrial-dependent pathway in MG-63 osteosarcoma cells. Mol. Med. Rep. 2011, 4, 1017-1023. [CrossRef] 
125. Lee, L.T.; Huang, Y.T.; Hwang, J.J.; Lee, P.P.H.; Ke, F.C.; Nair, M.P.; Kanadaswami, C.; Lee, M.T. Blockade of the epidermal growth factor receptor tyrosine kinase activity by quercetin and luteolin leads to growth inhibition and apoptosis of pancreatic tumor cells. Anticancer Res. 2002, 22, 1615-1627.

126. Deka, S.; Gorai, S.; Manna, D.; Trivedi, V. Evidence of PKC Binding and Translocation to Explain the Anticancer Mechanism of Chlorogenic Acid in Breast Cancer Cells. Curr. Mol. Med. 2017, 17, 79-89. [CrossRef]

127. Barahuie, F.; Saifullah, B.; Dorniani, D.; Fakurazi, S.; Karthivashan, G.; Hussein, M.Z.; Elfghi, F.M. Graphene oxide as a nanocarrier for controlled release and targeted delivery of an anticancer active agent, chlorogenic acid. Mater. Sci. Eng. C 2017, 74, 177-185. [CrossRef]

128. Hou, N.; Liu, N.; Han, J.; Yan, Y.; Li, J. Chlorogenic acid induces reactive oxygen species generation and inhibits the viability of human colon cancer cells. Anticancer Drugs 2017, 28, 59-65. [CrossRef] [PubMed]

129. Jiang, Y.; Satoh, K.; Watanabe, S.; Kusama, K.; Sakagami, H. Inhibition of chlorogenic acid-induced cytotoxicity by COCl2. Anticancer Res. 2001, 21, 3349-3353. [PubMed]

130. m/z cloud. Available online: https://www.mzcloud.org/ (accessed on 5 May 2020).

131. Pence, H.E.; Williams, A. Chemspider: An online chemical information resource. J. Chem. Educ. 2010, 87, 1123-1124. [CrossRef]

132. Yabuzaki, J. Carotenoids Database: Structures, chemical fingerprints and distribution among organisms. Database 2017, 2017, 1-11. [CrossRef] [PubMed]

133. FooDB. Available online: https://foodb.ca/ (accessed on 5 May 2020).

134. Ogata, H.; Goto, S.; Sato, K.; Fujibuchi, W.; Bono, H.; Kanehisa, M. KEGG: Kyoto encyclopedia of genes and genomes. Nucleic Acids Res. 1999, 27, 29-34. [CrossRef]

135. Lee, M.S.; Lee, S.O.; Kim, K.R.; Lee, H.J. Sphingosine kinase-1 involves the inhibitory action of HIF- $1 \alpha$ by chlorogenic acid in hypoxic DU145 cells. Int. J. Mol. Sci. 2017, 18, 325. [CrossRef]

136. The LIPID MAPS ${ }^{\circledR}$ Lipidomics Gateway. Available online: https://www.lipidmaps.org (accessed on 5 May 2020).

137. Rothwell, J.A.; Perez-Jimenez, J.; Neveu, V.; Medina-Remón, A.; M’Hiri, N.; García-Lobato, P.; Manach, C.; Knox, C.; Eisner, R.; Wishart, D.S.; et al. Phenol-Explorer 3.0: A major update of the Phenol-Explorer database to incorporate data on the effects of food processing on polyphenol content. Database 2013, 2013. [CrossRef]

138. Plant Metabolics Network (PMN). Available online: www.plantcyc.org (accessed on 5 May 2020).

139. Ramirez-Gaona, M.; Marcu, A.; Pon, A.; Guo, A.C.; Sajed, T.; Wishart, N.A.; Karu, N.; Djoumbou Feunang, Y.; Arndt, D.; Wishart, D.S. YMDB 2.0: A significantly expanded version of the yeast metabolome database. Nucleic Acids Res. 2016, 45, D440-D445. [CrossRef]

140. Kim, S.; Thiessen, P.A.; Bolton, E.E.; Chen, J.; Fu, G.; Gindulyte, A.; Han, L.; He, J.; He, S.; Shoemaker, B.A.; et al. PubChem substance and compound databases. Nucleic Acids Res. 2016, 44, D1202-D1213. [CrossRef]

141. Kim, S.; Chen, J.; Cheng, T.; Gindulyte, A.; He, J.; He, S.; Li, Q.; Shoemaker, B.A.; Thiessen, P.A.; Yu, B.; et al. PubChem 2019 update: Improved access to chemical data. Nucleic Acids Res. 2019, 47, D1102-D1109. [CrossRef]

142. PubMed. Available online: www.pubmed.ncbi.nlm.nih.gov (accessed on 5 May 2020).

143. Kim, S.; Thiessen, P.A.; Cheng, T.; Yu, B.; Bolton, E.E. An update on PUG-REST: RESTful interface for programmatic access to PubChem. Nucleic Acids Res. 2018, 46, W563-W570. [CrossRef] [PubMed]

144. Wang, Y.; Xiao, J.; Suzek, T.O.; Zhang, J.; Wang, J.; Zhou, Z.; Han, L.; Karapetyan, K.; Dracheva, S.; Shoemaker, B.A.; et al. PubChem's BioAssay Database. Nucleic Acids Res. 2012, 40, D400-D412. [CrossRef] [PubMed]

145. Kim, S.; Thiessen, P.A.; Cheng, T.; Zhang, J.; Gindulyte, A.; Bolton, E.E. PUG-View: Programmatic access to chemical annotations integrated in PubChem. J. Cheminform. 2019, 11, 56. [CrossRef] [PubMed]

Publisher's Note: MDPI stays neutral with regard to jurisdictional claims in published maps and institutional affiliations. 